\title{
Milan Pelc
}

Institut za povijest umjetnosti, Zagreb

\section{Utilissimus reipublicae princeps - Eugen Savojski i retorika barokne medalje}

\author{
Izvorni znanstveni rad - Original scientific paper \\ Primljen - Received 14. 7. 2020. \\ UDK 7.044:737.2Savojski, E
}

DOI doi.org/10.31664/ripu.2020.44/1.07

\begin{abstract}
Sažetak
Medalje posvećene Eugenu Savojskom pružaju reprezentativan uvid u baroknu vizualnu simboliku kao sastavnicu javne promidžbe istaknutog pojedinca. Njihova ikonografska analiza razotkriva mitopoetiku carskog vojskovode, ostvarenu s pomoću retoričkih sredstava barokne vizualne propagande, u prvom redu obilatim korištenjem izražajnih motiva portretne, mitološke, biblijske, amblemske i povijesno-topografske provenijencije. Obrađena numizmatička grada čuva se pretežno u zbirkama Arheološkog muzeja u Zagrebu i Muzeja Slavonije u
\end{abstract}

Osijeku. Da bi se bolje razumjela vizualna retorika kojom se stvarao image Eugena Savojskog, medaljama iz tih zbirki pridružene su $i$ druge medalje odnosno vizualna grada iz relevantnih suvremenih publikacija posvećenih velikom vojskovodi. Možda više nego u drugim likovnim medijima, princ Eugen je upravo na medaljama stiliziran kao utilissimus reipublicae princeps, kao produžena vojnička ruka triju careva $i$ kao njihov alter ego u borbi za interese Carstva.

Ključne riječi: Eugen Savojski, barokna medalja, Leopold I., Josip I., Karlo VI.

U složenom vizualnom apparatusu razvijenom za oblikovanje imagea važnih i znamenitih osoba, medalje su u 17. i 18. stoljeću imale istaknuto i prestižno mjesto. U Europi ranoga novoga vijeka one su - po uzoru na antičke modele - $\mathrm{u}$ prvom redu bile važni alati medijske operative namijenjene veličanju vladara i vojskovođa - onih koji su po prirodi stvari najviše utjecali na život ljudi svojega vremena. U komuniciranju zbivanja oko vladara i njegova života medalje su, jednako kao i drugi masovni mediji, imale ulogu važnih nositelja i sustvaratelja političke ikonografije vlasti primjerene određenoj razini kulturne recepcije suvremenika. ${ }^{1} \mathrm{U}$ široko zasnovan ikonografski program monarhijske promocije ušao je zahvaljujući svojim vojnim uspjesima i princ Eugen Savojski (1663. - 1736.), vojskovođa trojice habsburških careva, Leopolda I., Josipa I. i Karla VI. Po broju emitiranih medalja Eugen Savojski ubraja se među najpopularnije osobe svoga vremena. No njegova popularnost bila je, poput njega samoga, u službi promocije vladara i Carstva za koje se s uspjehom borio na mnogim bojištima od sjeverne Italije, Belgije i južne Njemačke do Ugarske i Otomanskog Carstva. Budući da je dobar dio Eugenove vojne aktivnosti izravno povezan s oslobađanjem hrvatskih povijesnih krajeva od Osmanlija, ne čudi što su dvije najveće numizmatičke zbirke sjeverne Hrvatske, ona Arheološkog muzeja u Zagrebu i ona Muzeja Slavonije u Osijeku, prikupile znatan broj medalja posvećenih proslavljenom vojskovođi. Premda su neke od njih bile izložene $u$ različitim prigodama, a neke su i pojedinačno kataloški opisane, te su medalje kao svojevrstan korpus primijenjene vizualne komunikacije iz baroknog vremena ostale uglavnom nezamijećene. ${ }^{2}$ Ovaj pokušaj njihove ikonografske interpretacije - u sklopu cjelokupnog nasljeđa Eugenove numizmatičke fortune - predstavit će ih kao specifično sredstvo medijske reprezentacije jednog od vodećih pripadnika političke elite svoga doba.

\section{Valuta fame}

U vizualnoj komunikaciji ranoga novoga vijeka osobito je važna uloga medalja u skupini onih medija čija učinkovitost počiva na uzajamnom djelovanju slike i teksta (natpisa). ${ }^{3}$ To naročito vrijedi za barokno doba kad proizvodnja medalja 
postaje uistinu masovnom. Premda je reprezentacijska funkcija medalje po uzoru na antičku tradiciju u europskome medijskom prostoru zamjetljiva od konca 14. stoljeća - u tom smislu najranijima se smatraju medalje padovanskog vojvode Francesca II. de Carrare - tek je koncem 17. stoljeća potencijal medalje kao sredstva za propagandu i stvaranje imagea istaknutih (političkih) osoba iskorišten u potpunosti. ${ }^{4}$ Već prema materijalima od kojih su napravljene (zlato, srebro, bronca, kositar) medalje su medij kojim su se društveno značajni sadržaji mogli komunicirati prema primaocima iz elitnog i razmjerno širokoga srednjeg društvenog sloja. Porast potražnje i omiljenost među publikom baroknoga doba potiču njihovu proizvodnju u velikim nakladama. ${ }^{5}$ Kao lako prenosivi, trajni, u materijalnom i estetskom smislu vrijedni predmeti reprezentacije i memorije, medalje su već od renesanse postale valutom fame. ${ }^{6}$ Taj aspekt njihova značenja u javnosti snažno se profilira u barokno doba, o čemu na reprezentativan način svjedoče i medalje posvećene Eugenu Savojskom.

Prvo što nam pri pokušaju određivanja numizmatičkog profila princa Eugena Savojskog upada u oči jest, dakako, njegov vojnički karakter. Princ Eugen na medaljama je isključivo prikazan i slavljen kao vojskovođa. Anonimni autor predgovora suvremene biografije princa Eugena ilustrirane medaljama, objavljene 1736., u godini njegove smrti, pod naslovom Eugenius nummis illustratus, retorički postavlja pitanje: »Nije li čitav život našeg hrabrog i pobjedama proslavljenog princa veličanstveno velika pozornica na kojoj se pred očima promatrača prikazuju junačka djela, bitke, pobjede, opsade i osvajanja? « Vizualnom odrazu te pozornice pripadale su, između ostalog, i medalje kovane u njegovu čast.

Kao što je poznato, Eugen je stupio u službu cara Leopolda I. neposredno uoči opsade Beča, u rujnu 1683. godine. Sudjelovao je u bitci pod Bečom i u kasnijim vojnim operacijama na tlu Ugarske. Ranjen je u opsadi Budima 1684. godine. U presudnoj bitci na Mohačkom polju ljeti 1687. istaknuo se izuzetnom hrabrošću. Zbog toga mu je pripala čast da prvi odnese vijest o pobjedi na bečki dvor. Godine 1688. sudjelovao je u osvajanju Beograda, pri čemu je također ranjen, ali je i promaknut u čin feldmaršala poručnika. Ključno je u njegovoj vojnoj karijeri bilo promaknuće u vrhovnog zapovjednika carskih snaga u Ugarskoj 1697. godine. Već $\mathrm{u}$ jesen te godine izvojevao je veliku pobjedu u bitci kod Sente, nakon koje je uslijedio mir u Sremskim Karlovcima 1699. godine. Od 1700. jedan je od glavnih zapovjednika na strani Habsburga u vojnim operacijama tijekom Rata za španjolsko nasljedstvo protiv Francuza i njihovih saveznika, koji je završio mirom u Rastattu 1714. godine. Nakon uspješnih vojnih operacija u sjevernoj Italiji, južnoj Njemačkoj, Nizozemskoj, Francuskoj i Belgiji prebacuje se na ratišta istočnog dijela carstva. Već ljeti 1716. pobjeđuje u bitci kod Petrovaradina, u jesen iste godine osvaja strateški važan Temišvar, a 1717. osvaja Beograd, nakon čega je 1718. uslijedio mir u Požarevcu.

Prema broju medalja posvećenih nekoj političkoj osobi na području Habsburške Monarhije u kasnom 17. i ranom
18. stoljeću Eugen Savojski je prvi nakon careva kojima je služio. Nijedan carski vojskovođa u doba nakon opsade Beča, od kojih su neki, poput Karla Lotarinškoga i Ljudevita Badenskoga, imali istaknute uloge u ratnim operacijama za oslobađanje Ugarskoga Kraljevstva, nije stekao toliku popularnost koja bi se odražavala u produkciji medalja kao Eugen Savojski. On je u tome daleko nadmašio svog bratića, grofa Ljudevita Badenskoga (1655. - 1707.), nazvanog Türkenlouis, koji se nakon opsade Beča 1683. proslavio u borbama protiv Osmanlija u Ugarskoj, poslije i protiv Francuza i njihovih saveznika u Ratu za falačko nasljedstvo (Pfälzischer Erbfolgekrieg). Kao vojni zapovjednik princ Eugen bio je od 1697. godine njegov izravni nasljednik na »istočnom « frontu. Na medaljama Ljudevita Badenskoga s početka devedesetih godina, emitiranim pretežno iz atelijera medaljera u Augsburgu, Nürnbergu i Beču, koji su poslije radili i medalje princa Eugena, primateljima je ponuđen niz značenjski srodnih propagandnih obrazaca i vizualnih motiva, koji su dolazili iz zajedničkog fonda barokne vizualne retorike. Valja, međutim, istaknuti da Eugen nije ovjekovječen samo na stvarnim medaljama. Eugen Savojski dobio je i biografiju ilustriranu medaljama koje nikad nisu kovane, dakle fiktivnim medaljama. Jedan od njegovih velikih poklonika Eugen Victor Mandacher objavio je 1735. u Beču disertaciju u kojoj opisuje Eugenov život od njegova ulaska u carsku službu 1683. pa sve do posljednjeg vojnog pohoda 1734. godine. ${ }^{8}$ Svi su važniji momenti Eugenove povijesti ilustrirani izmišljenim medaljama. Eugen Viktor Mandacher bio je sin Simona Mandachera koji je služio princu Eugenu kao tajnik i opunomoćenik u Nizozemskoj od 1706. do dvadesetih godina 18. stoljeća. Eugen je Victoru bio krsni kum. Svojom knjigom sastavljenom od triju odsječaka - prema carevima kojima je Eugen služio - autor je htio odati počast i iskazati svoju odanost velikom vojskovođi. U Mandacherovoj knjizi otisnuto je preko 70 bakropisnih ilustracija koje su zapravo medaljonski amblemi s odgovarajućim vizualnim i verbalnim porukama. ${ }^{9}$ Premda ne odražavaju sadržaje stvarnih Eugenovih medalja, te su ilustracije karakterističan primjer onovremenog »razmišljanja u medaljama «. ${ }^{10}$ Osim toga, one posreduju mnoge retoričke motive zajedničke vizualnoj reprezentaciji i promidžbi istaknutih vojskovođa i političara toga vremena.

Premda je princ Eugen slavljen i kao mecena, ljubitelj umjetnosti, kolekcionar, vlasnik zadivljujuće knjižnice i brojnih umjetničkih djela, ti se aspekti njegove "duhovne" djelatnosti na medaljama ne pojavljuju. Među više od 200 medalja iz njegova vremena, posvećenih izravno princu Eugenu, nema ni jedne jedine koja bi tematizirala bilo koji aspekt njegove intelektualne ili duhovne ličnosti. ${ }^{11} \mathrm{U}$ Mandacherovoj knjizi dvije su izmišljene medalje koje iznose sadržaje povezane s Eugenovim interesima za umjetnost, no i one su stavljene u funkciju veličanja Eugenove ratničke veličine. Na jednoj je prikazan njegov dvorac Belvedere u Beču kao dostojno sjedište koje ratniku pruža užitak u trenutcima opuštanja (sl. 1). ${ }^{12}$ Ta medalja ilustrira tekst u kojem je osim dvorca Belvedere opisana i Eugenova gradska palača s velikim kipom Herkula na stubištu, s reljefima na pročelju koji prikazuju Herkulove pothvate i s raznovrsnom umjetničkom opremom. Herkulskom simbolikom prožeta je sva Eugenova ikonografija 


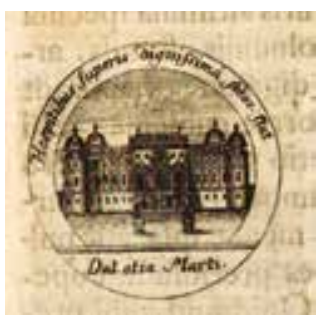

1. Medaljon s prikazom dvorca Belvedere u Beču, bakropis u: Eugen Victor Mandacher, Acta serenissimi principis Eugenii Francisci Sabaudiae et Pedemontij Ducis (...), Viennae, 1735., 133, Beč, Österreichische Nationalbibliothek

Medallion depicting the Belvedere Palace in Vienna, copperplate engraving in: Eugen Victor Mandacher, Acta serenissimi principis Eugenii Francisci Sabaudiae et Pedemontij Ducis (...), Vienna, 1735, 133, Vienna, Österreichische Nationalbibliothek

koju je Mandacher 1735., godinu dana prije Eugenove smrti, mogao sagledati u panoramskoj retrospektivi. Druga ilustracija intelektualnog karaktera otisnuta je na početku teksta u kojem je opisana Eugenova znamenita knjižnica (sl. 2). Ta "medalja“ spaja simboliku Herkula s radom muza, posvećenim samom princu Eugenu, »Mecenatu svoga doba«, kako stoji u njezinomu donjem dijelu. Naime, Herkul iz pozadine promatra muze kojima je glavna tema princ Eugen: u prednjem planu jedna crta njegovo poprsje, druga slika njegov portret, treća piše o njemu itd. ${ }^{13} \mathrm{Na}$ "medalji" je moto iz Klaudijanove poeme: Gaudet enim virtus testes sibi jungere musas (Raduje se hrabrost kad o njoj svjedoče muze.).

Niti jedan vojskovođa nije imao toliko uspjeha u ratovima za habsburšku carsku kuću kao princ Eugen Savojski. Vodeći borbe i pobjeđujući na dva fronta, Eugen je stiliziran u pobjednika nad Osmanlijama i nad Francuzima - glavnim neprijateljima austrijske krune u kršćanskom svijetu. U komunikacijskoj perspektivi svoga vremena on se javlja kao osloboditelj i zaštitnik kršćana, odnosno kao osvetnik nad nepravdama nanesenima Carstvu. Na njegov moralni lik uzornog vojskovođe aludira biblijski citat iz knjige o Makabejcima, otisnut na početku posmrtnoga govora što ga je nad njegovim odrom u bečkoj katedrali održao katedralni propovjednik, isusovac Franz Peikhart: »Et iste quidem hoc modo vita decessit [non solum juvenibus sed et] universae genti memoriam mortis suae ad Exemplum Virtutis \& Fortitudinis derelinquens. "(Tako je on preminuo i svojom smrću ostavio ne samo mladeži nego i većini naroda primjer hrabrosti i spomenik kreposti. 2. Makabejci, 6, 31). ${ }^{14}$ Peikhartov posmrtni govor vrlo je poučan jer sažima najvažnije aspekte javne stilizacije Eugenove ličnosti i njegovih zasluga za Carstvo. Većim dijelom on je posvećen vojničkim vrlinama princa Eugena koje se uvezuju u antičku i biblijsku tradiciju bogova i heroja poput Marsa, Merkura, Herkula, Ahila, Odiseja, Hanibala, Jošue i Gideona.

\section{Princ Eugen kao vojnički alter ego habsburških careva}

Zahvaljujući pobjedama nad neprijateljima Habsburške Monarhije koncem 17. i početkom 18. stoljeća, Eugen Sa-

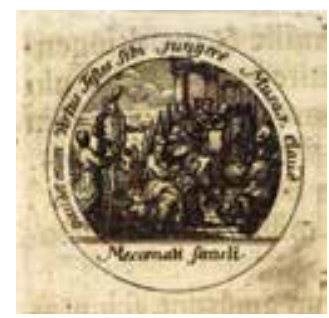

2. Medaljon s prikazom Herkula, princa Eugena i muza, bakropis u: Eugen Victor Mandacher, Acta serenissimi principis Eugenii Francisci Sabaudiae et Pedemontij Ducis (...), Viennae, 1735., 135, Beč, Österreichische Nationalbibliothek

Medallion depicting Hercules, Prince Eugene, and the Muses, copperplate engraving in: Eugen Victor Mandacher, Acta serenissimi principis Eugenii Francisci Sabaudiae et Pedemontij Ducis (...), Vienna, 1735, 135, Vienna, Österreichische Nationalbibliothek

vojski ušao je u samu srž carske političke mitopoetike, a jedan od njezinih omiljenih medija bila je upravo medalja kao »najvažnija izražajna forma ranonovovjeke političke ikonografije «. ${ }^{15}$ Eugen je carski vojskovođa - njegova je slava ujedno i slava carske kuće. Ključno je u njegovoj javnoj stilizaciji nepomućeno isticanje vjernosti i bezrezervne odanost habsburškim carevima, kojima je lojalno služio 53 godine, presudno pridonijevši njihovoj veličini i veličini carstva. ${ }^{16}$ Kako se vidi na nekim njegovim grafičkim portretima, Eugen je u kasnom razdoblju svoje karijere tituliran kao »imperator exercitus «. ${ }^{17}$ Oko tog naslova najvećim je dijelom programirana ikonografija vojskovođe. On je služio vladarima koji su se, doduše, dičili naslovima imperatora, no jedino je princ Eugen bio istinski imperator u vojničkom smislu, a njegovi su vojni uspjesi legitimirali imperatorsku titulu samih careva, koji su se vrlo rijetko pojavljivali na bojištu. ${ }^{18}$ Kao glavni zapovjednik vojske i predsjedavajući dvorskoga ratnog vijeća (Hofkriegsrat), princ Eugen bio je produžena vojna ruka habsburških careva, njegovi su uspjesi bili njihovi uspjesi, njegova reprezentacija bila je istodobno i njihova.

Na medalji koju je Philipp Heinrich Müller osmislio u povodu pobjede nad Francuzima kod Cremone 1702. godine princ Eugen prezentiran je kao carev osvetnik (sl. 3). ${ }^{19} \mathrm{U}$ medaljonu od palminih grana prikazano je njegovo poprsje s natpisom uz donji rub koji ističe njegovu titulu glavnog zapovjednika carske vojske. Natpis uz gornji obod medalje Patiens vocari caesaris ultor (Može ga se zvati carevim osvetnikom) predstavlja vojskovođu kao izvršitelja careve osvete nad neprijateljima. ${ }^{20}$ Car je simbolički prisutan u liku orla koji je kandžama zgrabio velikoga galskog pijetla, dok četiri manja bježe na razne strane. Na stražnjoj strani medalje glavni su motiv ljiljani koje savija vjetar, s natpisom Flantibus austris (Dok puše južni vjetar.), pri čemu je austris, dakako, verbalna aluzija na Austriju, tj. Habsburško Carstvo. ${ }^{21} \mathrm{Na}$ njega se nadovezuje natpis na obodu medalje: Florentes ferulas et grandia lilia quassans (Odnoseći cvjetove sa stapki, tresući velike ljiljane). ${ }^{22}$ Carstvo je simbolički nazočno i na drugoj strani medalje gdje se na štit s dvoglavim habsburškim orlom naslonila personifikacija (njemačke) hrabrosti s malim kipićem viktorije u lijevoj ruci. Alegorijski prizori s obje strane medalje podrugljive su aluzije na slabost fran- 

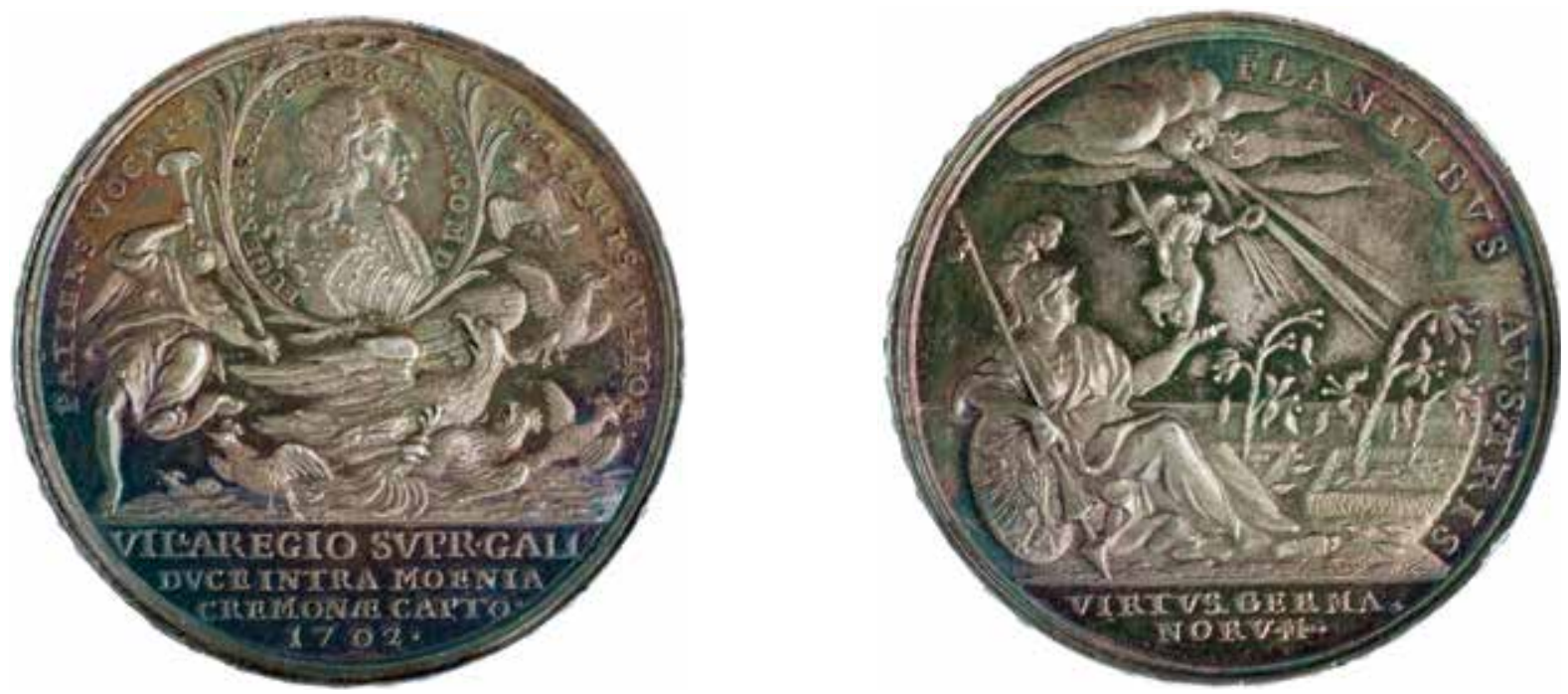

3. Philipp Heinrich Müller, medalja uz bitku kod Cremone, 1702., Zagreb, Arheološki muzej, inv. br. 7619 Philipp Heinrich Müller, medal commemorating the Battle of Cremona, 1702, Zagreb, Archaeological Museum, Inv. No. 7619


4. Benedikt Richter, W. Hoffmann, medalja uz vojni pohod na rijeku Mosel, 1735., Muzej Slavonije Osijek, inv. br. 7184

Benedikt Richter, W. Hoffmann, medal commemorating the military campaign on the Mosel, 1735, Osijek, Museum of Slavonia, Inv. No. 7184

cuske vojske koju je porazio i u bijeg natjerao carski osvetnik - princ Eugen, kojemu je pritom u ruke pao francuski zapovjednik, maršal François de Neufville Duc de Villeroy. ${ }^{23}$ Izrugivanje protivnika dopunjeno je latinskim citatima koje su mogli razumjeti samo obrazovani suvremenici. Jedna kasna medalja Benedikta Richtera i W. Hoffmanna, kovana na kraju Eugenove karijere u povodu (neuspjeloga) vojnog pohoda protiv Francuza na rijeci Mosel 1735. godine (sl. 4) poseže na reversu za sličnim motivima podrugljive retorike: francuska vojska ukopana u snažna poljska utvrđenja, ustrašena pojavom princa Eugena, izvrgnuta je podsmjehu rečenicom u natpisu: Gallorum virtus ad speluncas redacta (Hrabrost Francuza stjerana u rupe). ${ }^{24}$

Na medalji Petera Paula Wernera uz bitku kod Temišvara 1716. godine natpis navodi: Oružjem, postojanošću i snagom cara po Eugenu (sl. 5). ${ }^{25} \mathrm{Na}$ toj, kao i na nizu drugih medalja kovanih u spomen Eugenovih pobjeda, pojavljuje se na aversu umjesto njegovoga carev portret, koji naznačava da je zapravo car zaslužan za ratne uspjehe svoga vojskovođe i da svaka njegova pobjeda pridonosi carevoj veličini i jačanju carstva. U ikonografiji pobjede Eugen je na medalji, kao i u bitci, mogao biti carev alter ego. Na aversu medalje Martina Brunnera kovane uz osvajanje Beograda 1717. godine (sl. 6). prikazano je poprsje princa Eugena s odličjem Zlatnog runa, na glavi mu antikizirajuća Marsova kaciga ovjenčana lovorom i natpis Eugen(ius) Franc(iscus) dux Sabaud(iae) Summ(us) Caes(aris) exerc(itus) imper(ator). ${ }^{26} \mathrm{Na}$ reversu medalje Eugenu - Marsu odgovara prikaz boga rata i natpis: Alter Gradivi bellus gradus Belgrado obtenuto (Još jedan lijepi korak [Marsa] Gradivusa nakon osvajanja Beograda, kronogram 1717.). Igra riječi: 

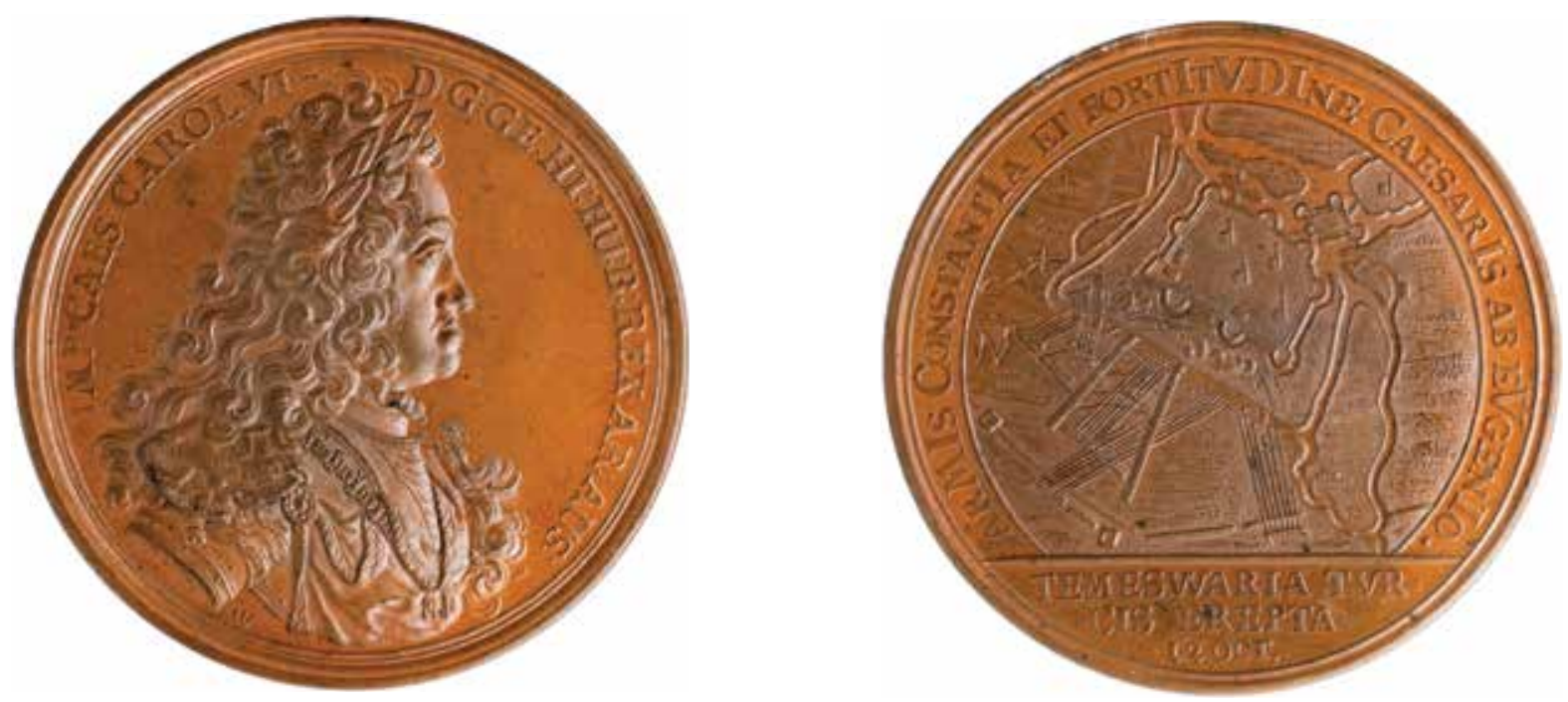

5. Peter Paul Werner, medalja uz bitku kod Temišvara, 1716., Zagreb, Arheološki muzej, inv. br. 7460 Peter Paul Werner, medal commemorating the Battle of Timișoara, 1716, Zagreb, Archaeological Museum, Inv. No. 7460
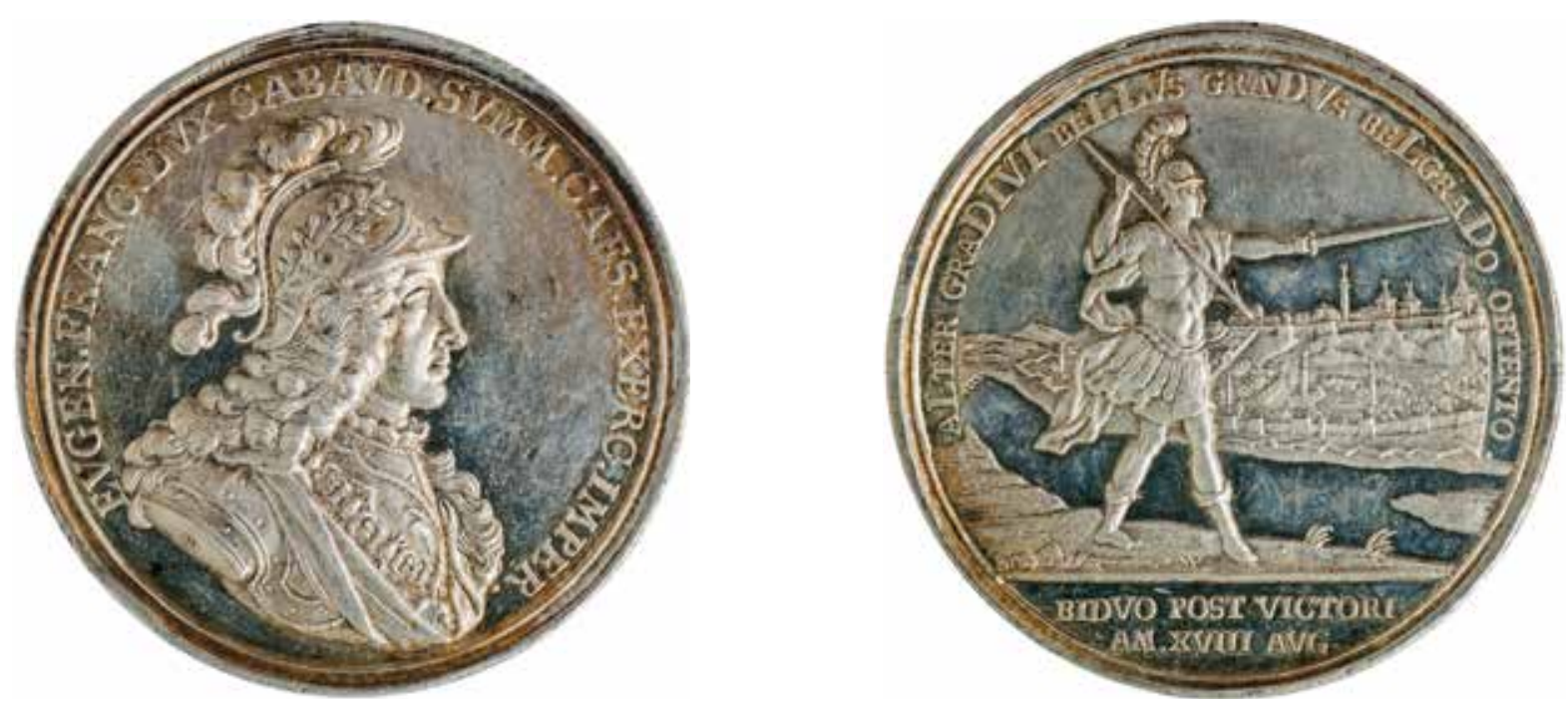

6. Martin Brunner, medalja uz osvajanje Beograda, 1717., Zagreb, Arheološki muzej, inv. br. 7475

Martin Brunner, medal commemorating the conquest of Belgrade, 1717, Zagreb, Archaeological Museum, Inv. No. 7475

Gradivus - bellus gradus - Belgradus i ovdje podrazumijeva određenu intelektualnu spremu primalaca medalje. Naime, Mars Gradivus je jedna od inačica boga Marsa kojem se vojnici i vojskovođe zaklinju na hrabrost u ratu. Naziv Gradivus dolazi od stupanja u maršu kojim se odlazi u bitku. Ista medalja s posve istim reversom kovana je i u inačicama na kojima je sprijeda umjesto Eugenova prikazano poprsje cara Karla VI. ${ }^{27}$

U egzekutivnom političkom i diplomatskom smislu Eugen je bio carev namjesnik u Italiji i Nizozemskoj. ${ }^{28}$ Kao carski opunomoćenik on je vodio ključne mirovne pregovore $\mathrm{u}$ Rastattu (1714.) i Požarevcu (1718.). O gotovo posvemašnjem poistovjećivanju cara i njegova pobjedničkog vojskovođe svjedoči, primjerice, i to da je nakon bitke kod Höchstädta 1704. godine, nakon koje je čitava južna Njemačka došla pod vlast Habsburga, car Leopold I. ovlastio princa Eugena da u njegovo ime preuzme iskaze odanosti (Erbhuldigung) bavarskih staleža. ${ }^{29}$

Mnogo je usporednih primjera poistovjećivanja vojskovođe s carem i u drugim medijima. Jedan od vizualnih vrhunaca dostignut je vjerojatno na bakrorezu Jana Wandelaara iz 1720. godine (sl. 7), otisnutom u možda najraskošnije ilustriranoj Eugenovoj ratnoj monografiji koja je osmišljena kao reprezentativni spomenik njegovim vojnim uspjesima u službi carstva. Upravo veličanstveni grafički prikazi najvažnijih Eugenovih bitaka Jana van Huchtenburgha u tom su djelu popraćeni komentarima i opisima povjesničara Jeana Dumonta. ${ }^{30}$ Bakrorez Jana Wandelaara s prikazom princa Eugena kao rimskog imperatora otisnut je na početku posvete. Princ Eugen kao pobjednik nad neprijateljima izjednačen je s Cezarom - na njegovom pojasu ucrtan je 


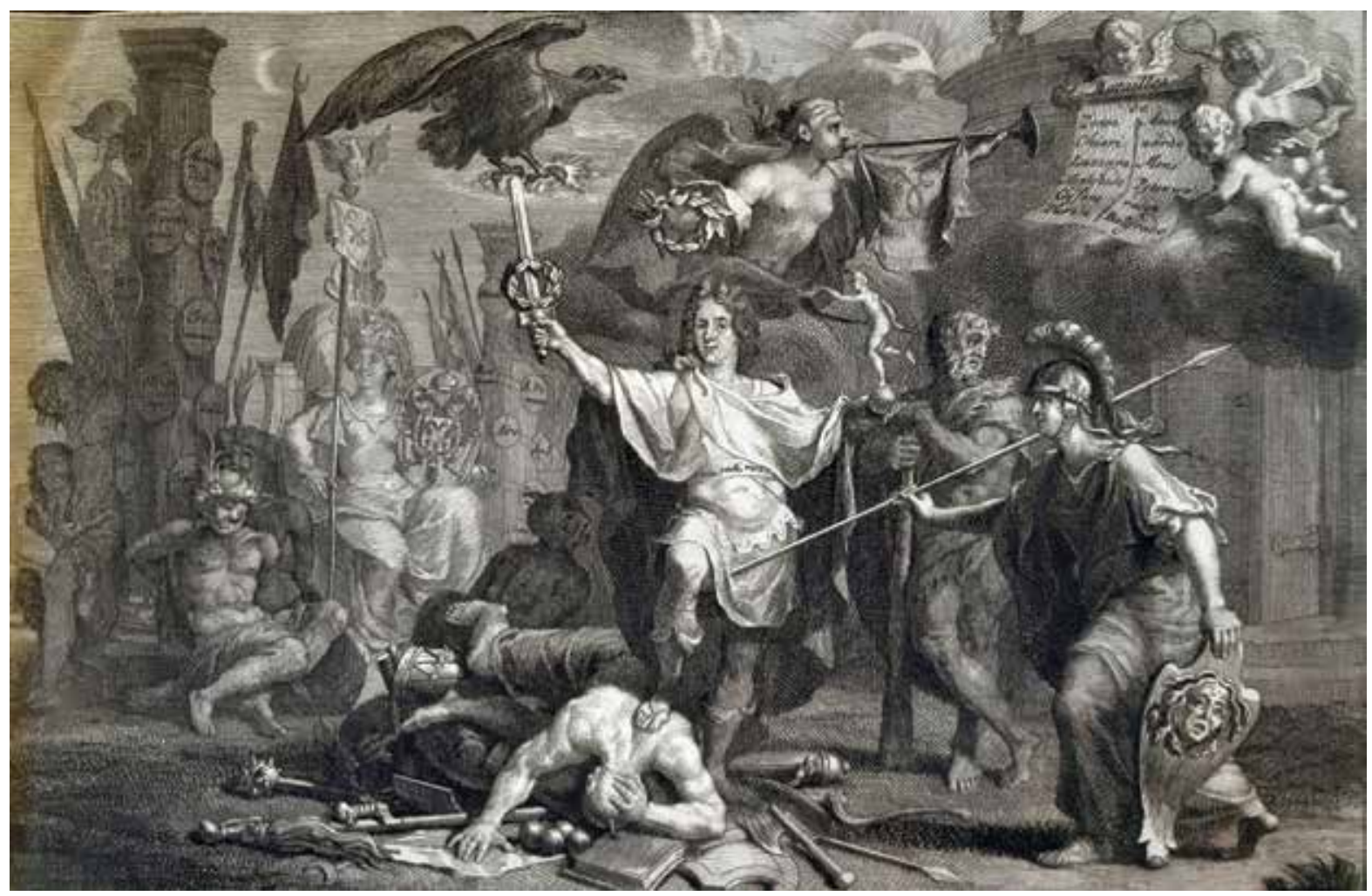

7. Jan Wandelaar, Princ Eugen kao imperator, bakrorez u: Jean Dumont - Jan van Huchtenburgh, Batailles gagnées par le serenissime prince Fr. Eugene De Savoye, A La Haye, 1720., Beč, Österreichische Nationalbibliothek

Jan Wandelaar, Prince Eugene as Emperor, copperplate engraving in: Jan van Dumont - Jean Huchtenburgh, Batailles Gagnées par le Serenissime Prince Fr. Eugene De Savoye, The Hague, 1720, Vienna, Österreichische Nationalbibliothek
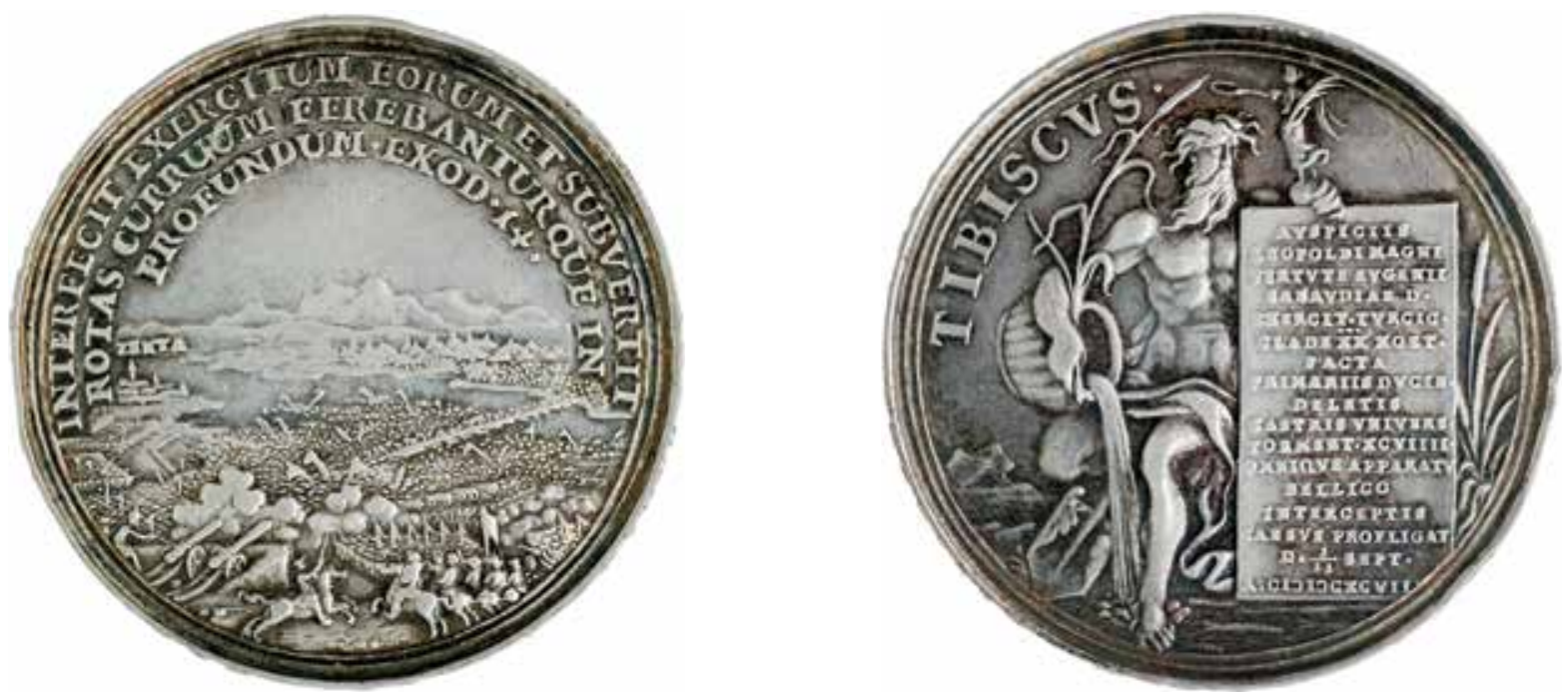

8. Georg Hautsch, medalja uz bitku kod Sente, 1697., Zagreb, Arheološki muzej, inv. br. 7209

Georg Hautsch, medal commemorating the Battle of Senta, 1697, Zagreb, Archaeological Museum, Inv. No. 7209

natpis Veni, vidi, vici. Iznad njegova lovorom ovjenčana mača lebdi carski (Jupiterov) orao, u pozadini na prijestolju sjedi personifikacija Habsburškog Carstva (Germania) sa štitom na kojem je dvostruki dvoglavi orao s carskom krunom. U desnoj ruci drži kršćanski palij. Pobjedniku Eugenu s njegove se lijeve strane pridružuju Minerva i Herkul, lijevom rukom on podiže kipić fortune koja balansira na kugli, s kosom okrenutom prema vojskovođi. Vještim spajanjem antičkih i kršćanskih motiva, simbolička retorika slike približava vojskovođu ikonografskom programu carske apoteoze.

S carevima kojima je odano služio, Eugen je dijelio mjesto na medaljama, bilo u liku, bilo u natpisu ili u alegorijskoj 

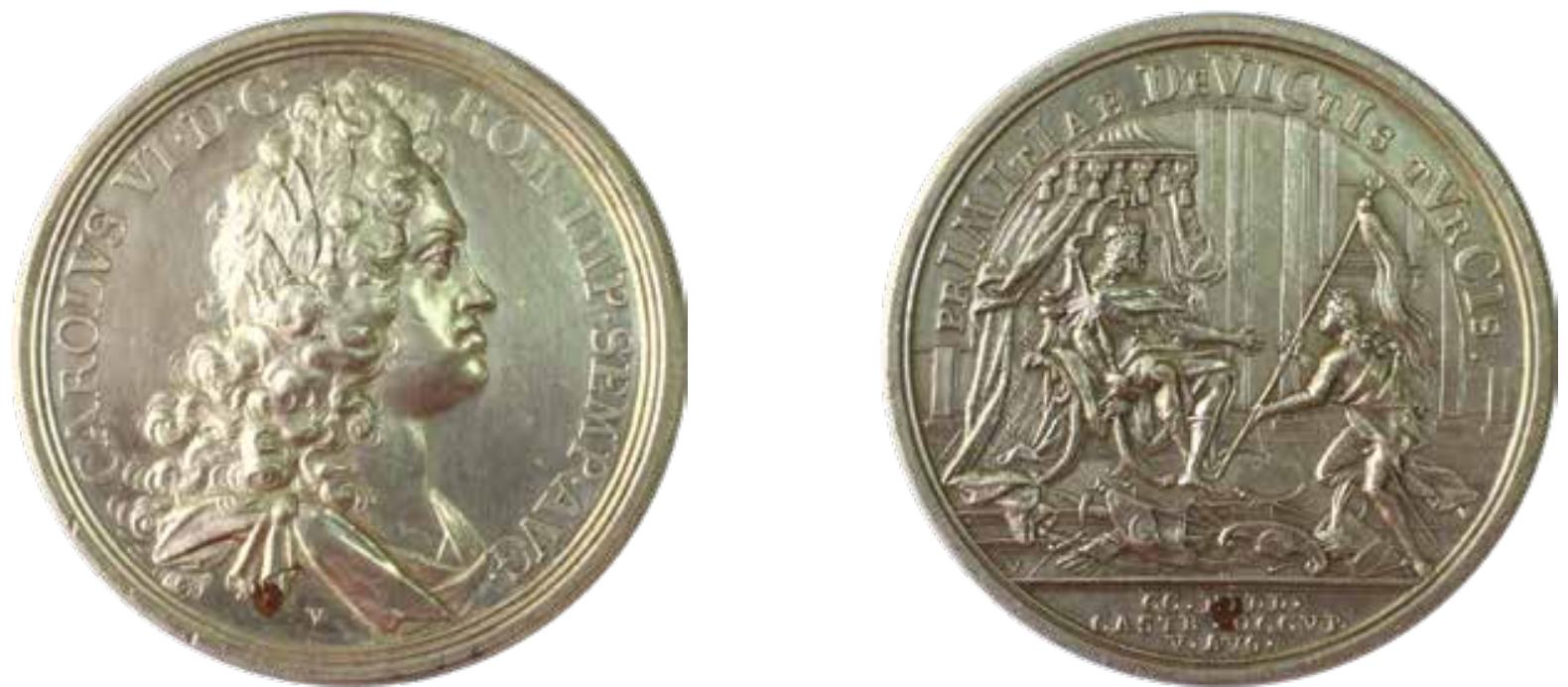

9. Georg Wilhelm Vestner, medalja uz bitku kod Petrovaradina, 1716., Muzej Slavonije Osijek, inv. br. Stari fundus

Georg Wilhelm Vestner, medal commemorating the Battle of Petrovaradin, 1716, Osijek, Museum of Slavonia, Inv. No. Stari fundus

sceni. Prvi put uopće Eugen se pojavio na medalji Georga Hautscha, kovanoj u spomen bitke kod Sente 1697. godine (sl. 8), koja mu je donijela europsku slavu velikog vojskovođe. Nakon te bitke uslijedio je mir u Srijemskim Karlovcima 1699. godine koji je Habsburzima osigurao posjed nad većim dijelom Ugarske, dotad pod osmanlijskom vlašću. ${ }^{31}$ Car Leopold I. prisutan je na toj medalji zahvaljući natpisu utisnutom na njezinom obodu: Gle, još jedan sretan trijumf iz zavjeta, o Leopolde, s kronogramom 1697. godine. Na aversu medalje prikazana je bitka na rijeci Tisi. Grad Senta označen je u pozadini na lijevoj strani. U prednjem planu prikazani su kršćanski topovi koji tuku neprijatelja. Do njih je eskadron konjanika sa zapovjednikom koji podiže zapovjedničku palicu, a koji bi po logici prikaza imao biti princ Eugen. ${ }^{32}$ Zbog malog formata, na medalji je prikaz bitke sveden na najosnovnije sastavnice, no unatoč sažetom raspolaganju prikazbenim vokabularom, intenzitet velike bitke dojmljivo je dočaran u širokome panoramskom prostoru. Važan je ovdje dugački natpis na gornjem obodu medalje, preuzet iz Knjige izlaska, 14, 24-27: [Za jutarnje straže pogleda Jahve iz stupa od ognja i oblaka na egipatsku vojsku i u njoj stvori zbrku.] "Zakoči točkove njihovih kola da su se jedva naprijed micali (...) Kako su Egipćani, bježeći, jurili prema moru, Jahve ih strmoglavi usred voda." Uspjeh bitke u kojoj je glavnina neprijateljske vojske stradala u vodama Tise pripisivao se čudesnoj Božjoj intervenciji. Vjerovalo se da je pobjedu nagovijestila čudotvorna slika Majke Božje iz sela Pötsch (Máriapócs) u istočnoj Ugarskoj, koja je u više navrata proplakala, da bi nakon bitke prestala. Slika je prenesena u bečku prvostolnicu i danas se još uvijek časti kao Madonna von Pötsch. Prema legendi, Madonna se pri napadu ukazala carskim vojnicima pred turskim rovovima. ${ }^{33}$

Na reversu medalje prikazan je riječni bog - personifikacija Tise s latinskim imenom TIBISCUS - $\mathrm{u}$ liku starca s vijencem od trske na glavi i ostalim atributima vodenog božanstva. Taj atletski modelirani lik lijevom rukom drži mali kipić antičke viktorije koja na njegovu glavu polaže vijenac pobjede. Istom rukom starac pridržava ploču s opširnim natpisom koji informira o zaslugama cara Leopolda I. i njegovog vojskovođe Eugena Savojskog u toj pobjedi: »Za vladavine Leopolda Velikog, hrabrošću princa Eugena Savojskog razbijena je i raspršena turska vojska uz gubitke od 20.000 vojnika i zapovjednika, pri čemu je zaplijenjen čitav logor, 99 topova i sva ratna oprema. 1./11. rujna 1697.« Kolika je bila popularnost te medalje svjedoče djela suvremenika, ponajprije spomenuti prinčev životopis Eugenius nummis illustratus iz 1736. godine u kojem su na zasebnom bakropisu vjerno reproducirane obje strane medalje, a njihovi opisi doneseni su u bilješci ispod teksta. ${ }^{34}$ Pritom su u opisima svi latinski citati prevedeni na njemački, čime je kompletan sadržaj medalje, i slika i tekst, u potpunosti učinjen dostupnim i onim čitateljima koji nisu razumjeli latinski jezik.

Gotovo dva desetljeća poslije Georg Wilhelm Vestner osmislio je u povodu bitke kod Petrovaradina medalju na kojoj se zajednički veličaju car Karlo VI. i princ Eugen (sl. 9). ${ }^{35}$ Prednja strana rezervirana je za profilni carev lik ovjenčan lovorom, dok se na stražnjoj strani odigrava simbolički susret Karla VI. koji sjedi na prijestolju pod baldahinom i princa Eugena koji mu na dugačkom koplju donosi znamenje konjskoga repa (Roßschweif) kao nepogrešiv znak pobjede nad Turcima. Na tlu razbacano leži oružje s bojnim zastavama otetim neprijatelju. Natpis Primitiae devictis Turcis (Prvi komadi plijena nakon pobjede nad Turcima, kronogram 1716.) potvrđuje da se radi o pobjedi koju precizira natpis pri dnu medalje, a on, ne navodeći mjesto bitke, naznačava da je 5. kolovoza pobijeđena vojska od 200000 vojnika i osvojen njezin logor. Georg Wilhelm Vestner izradio je s Philippom Heinrichom Müllerom još jednu medalju povodom petrovaradinske bitke, na kojoj je sprijeda carevo poprsje, a straga veliki tropej sačinjen od turskog oružja, zastava i konjskih repova na kopljima. ${ }^{36} \mathrm{Za}$ razliku od prethodne, na toj medalji natpisom je naznačen Petrovaradin kao mjesto bitke. Navođenje mjesta očigledno nije bilo presudno za 

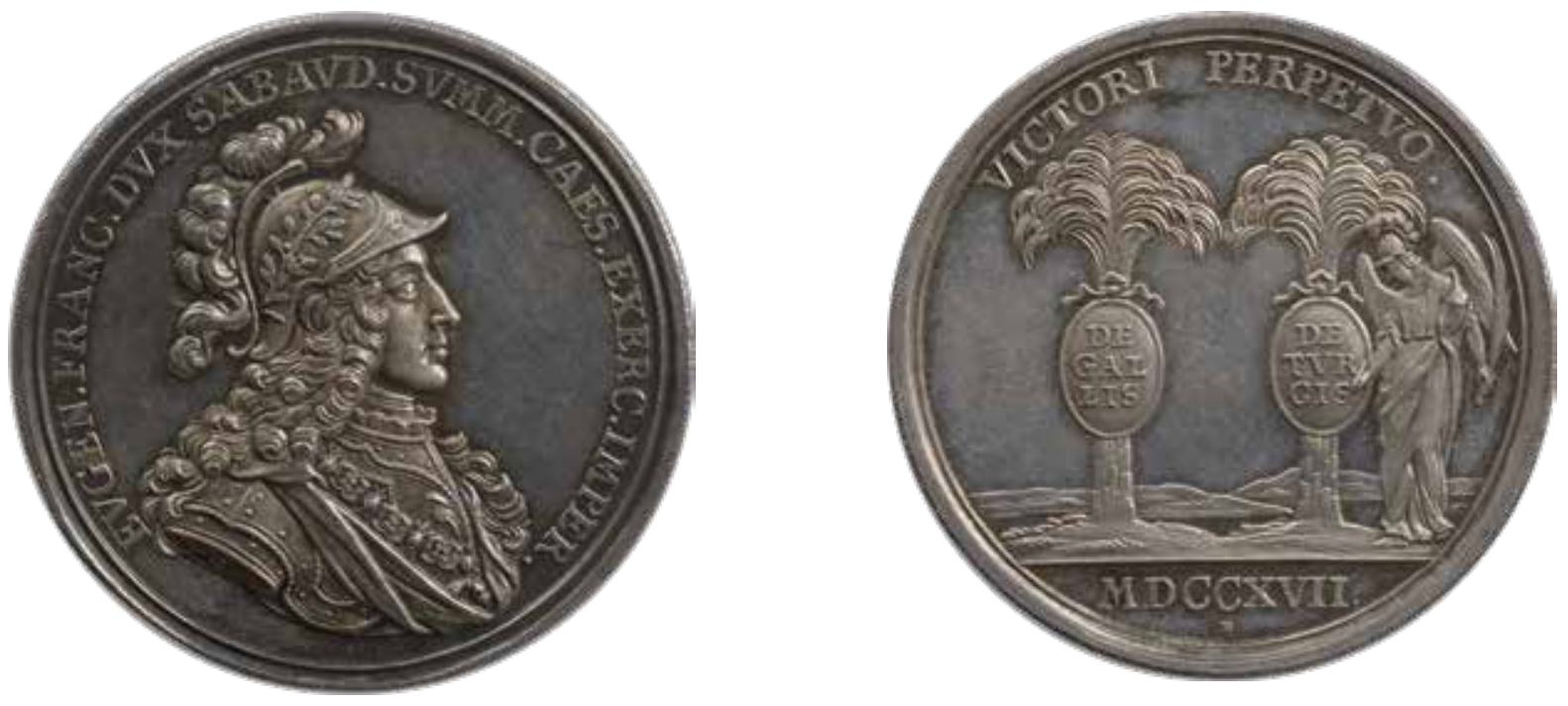

10. Martin Brunner (autor portreta), Georg Friedrich Nürnberger (autor alegorijskog prizora), medalja uz osvajanje Beograda, 1717., Beč, Kunsthistorisches Museum, Inv. Nr. 6509b $\beta$

Martin Brunner (author of the portrait), Georg Friedrich Nürnberger (author of the allegorical scene), medal commemorating the conquest of Belgrade, 1717, Vienna, Kunsthistorisches Museum, Inv. No. $6509 b \beta$

razumijevanje medalje koja se pojavljuje ažurno, kao jedan od mnogih nositelja vijesti o svima poznatom političkom događaju.

\section{Mars Hungaricus - Vicarius in Italia}

Princ Eugen je na medaljama, jednako kao i u drugim vizualnim medijima, s carevima dijelio mnoge ikonografske značajke. Medaljeri koji su stvarali njegov image u javnosti preuzimali su iz repertoara carske promidžbe u prvom redu simboličku identifikaciju s herojima antičke mitologije, Marsa, Minerve i Herkula, koji se na medaljama (i inače u prikazbenim umjetnostima) pojavljuju kao najčešći mitološki ekvivalenti vladarskim i vojničkim vrlinama Leopolda I., Josipa I. i Karla VI. ${ }^{37}$ Osim već opisane medalje na kojoj je Eugen idetificiran kao Mars Gradivus (sl. 6), njegovo poprsje, stilizirano u obličje Marsa, pojavljuje se na još jednoj medalji Martina Brunnera (autor portreta) i Georga Friedricha Nürnbergera (autor alegorijskog prizora), kovanoj u povodu osvajanja Beograda 1717. godine (sl. 10). ${ }^{38}$ Natpis ga slavi kao onoga koji stalno pobjeđuje (Victori perpetuo). Alegorija na reversu medalje objedinjuje njegove pobjede nad Francuzima i nad Osmanlijama: prikaz se sastoji od dvije palme, od kojih jedna nosi štit s natpisom De Galis, a druga De Turcis. Pored ove druge stoji lik viktorije s palminom granom u ruci. Nema oznake mjesta na koje se odnosi ko-
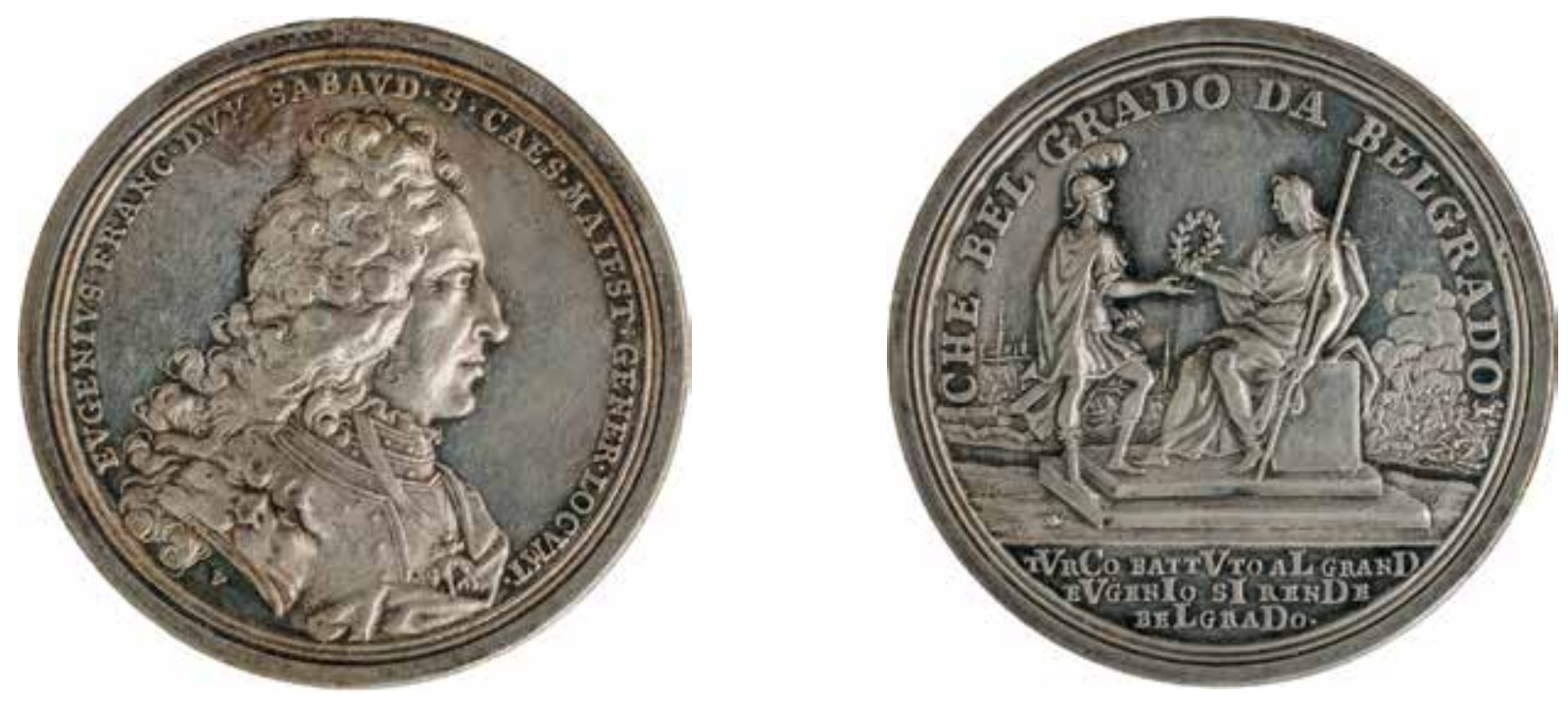

11. Georg Wilhelm Vestner, medalja uz bitku kod Beograda, 1717., Zagreb, Arheološki muzej, inv. br. 32304

Georg Wilhelm Vestner, medal commemorating the Battle of Belgrade, 1717, Zagreb, Archaeological Museum, Inv. No. 32304 

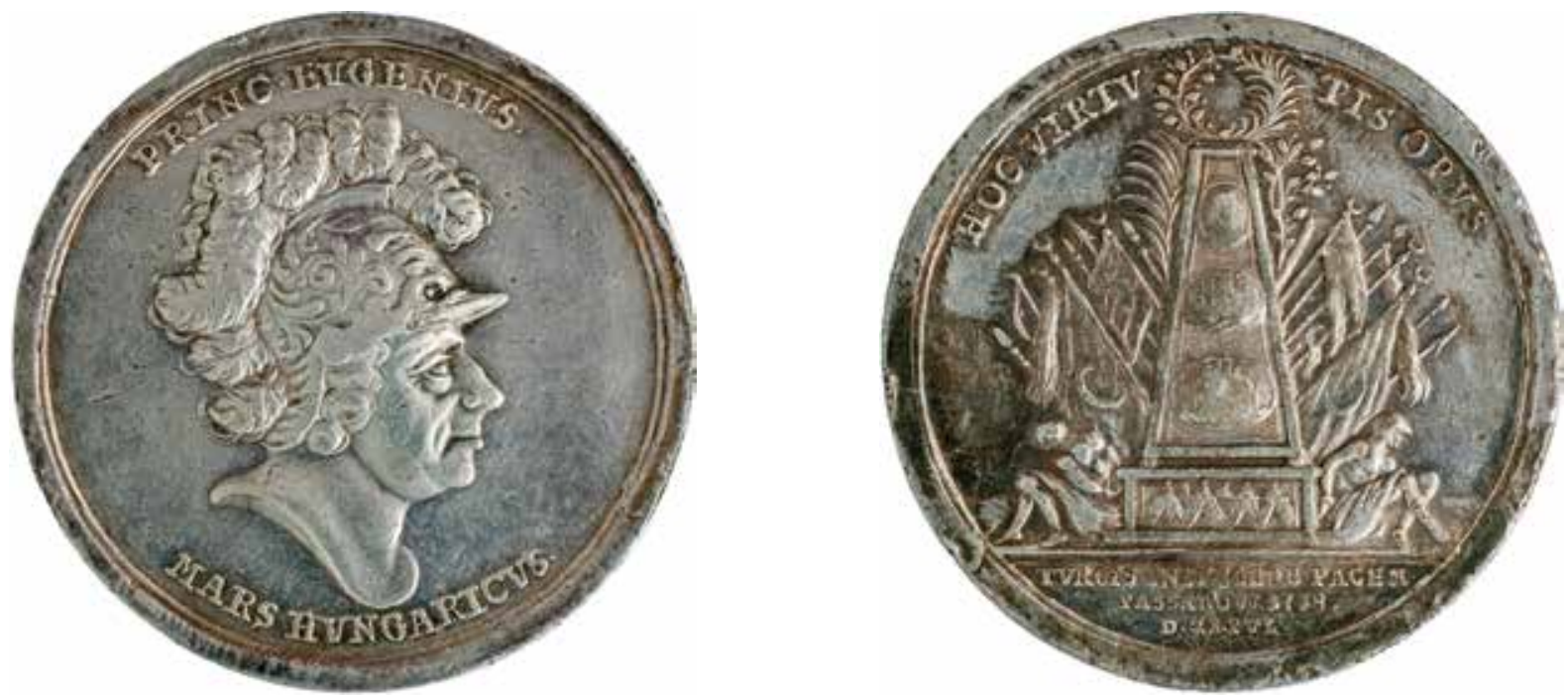

12. Nepoznati umjetnik, medalja uz osvajanje Beograda, 1717., Zagreb, Arheološki muzej, inv. br. 7496

Anonymous artist, medal commemorating the conquest of Belgrade, 1717, Zagreb, Archaeological Museum, Inv. No. 7496

13. Benedikt Richter, medalja u povodu imenovanja Eugena Savojskog carskim namjesnikom u Italiji, 1724., Zagreb, Arheološki muzej, inv. br. 32396

Benedict Richter, medal for the occasion of the appointment of Eugene of Savoy as imperial governor in Italy, 1724, Zagreb, Archaeological Museum, Inv. No. 32396

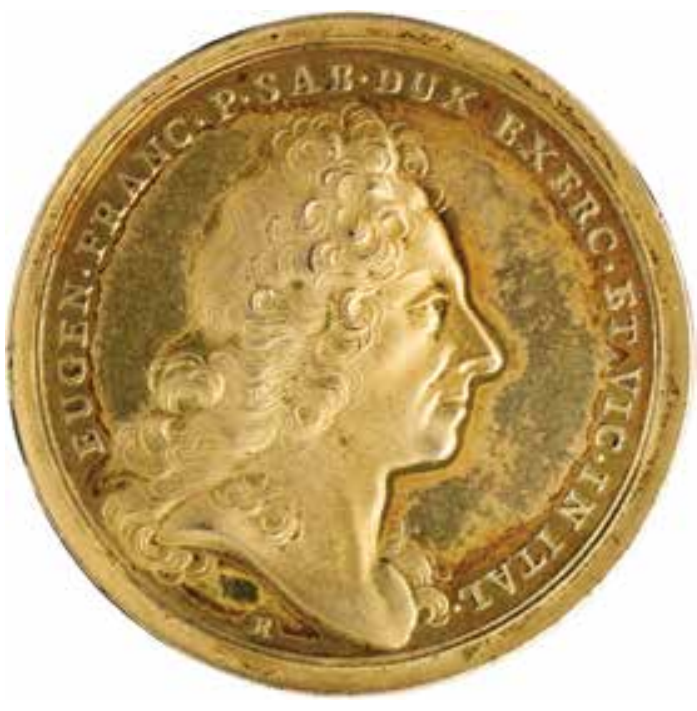

memoracija, no pri dnu reversa upisana je godina 1717. kao prepoznatljivo značenjsko sidro koje suvremenicima jasno denotira na koje se događaje medalja referira. Simbolička poveznica s bogom Marsom značenjska je okosnica i na medalji Georga Wilhelma Vestnera, kovanoj u slavu pobjede kod Beograda 1717. godine (sl. 11). ${ }^{39} \mathrm{Na}$ aversu prikazano je Eugenovo poprsje sa zlatnim runom i allonge-perikom, dok je na reversu alegorijski prizor u kojem se princ odjeven kao rimski ratnik - Mars uspinje prema tronu na kojem sjedi personifikacija besmrtnosti koja mu pruža lovorov vijenac. Talijanski natpis na obodu medalje Che bel grado da Belgrado (Lijepa li pristupa od Beograda) poigrava se nazivom grada u kojem odzvanja značenje Marsa Gradivusa i stupanjem pobjednika do vrhunca slave.

Mir u Požarevcu koji je uslijedio 1718. godine komemoriran je medaljama na kojima se kao glavni pobjednik pojavlju-

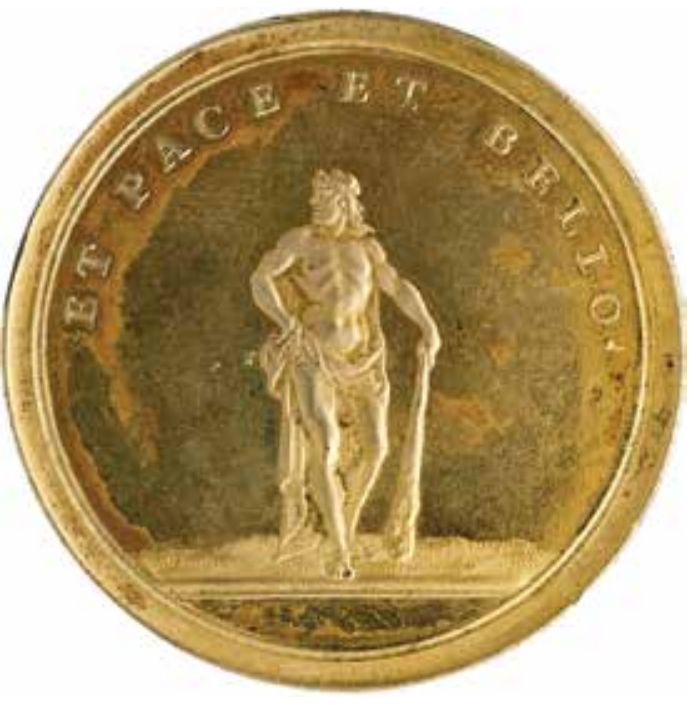

je car Karlo VI., a kao njegova vojnička produžena ruka princ Eugen. ${ }^{40} \mathrm{Na}$ jednoj anonimnoj medalji (sl. 12) on je na aversu i likom i natpisom stiliziran u Ugarskoga Marsa (Princ. Eugenius - Mars Hungaricus). ${ }^{41} \mathrm{Na}$ reversu prikazan je veliki tropej u obliku piramide s medaljonskim prikazima Beograda i Temišvara, iznad njih štit s polumjesecom, u podnožju šatori osvojenoga turskog tabora. Zarobljenici, osvojene zastave i konjski repovi na kopljima, raspoređeni oko tropeja, znakovi su potučene turske vojske, dok palmina i lovorova grana koji iz njih izlaze i savijaju se u vijenac iznad piramide simboliziraju pobjedu. Simbolika vojne pobjede popraćena je natpisom Hoc virtutis opus (To je djelo hrabrosti) koji stražnju stranu medalje povezuje s prednjom, tj. s princom Eugenom. Zahvaljujući njemu, Turcima je nametnut mir u Požarevcu (Turcis iniungere pacem!), kojim je pod vlast krune povraćeno čitavo Ugarsko Kraljevstvo. 


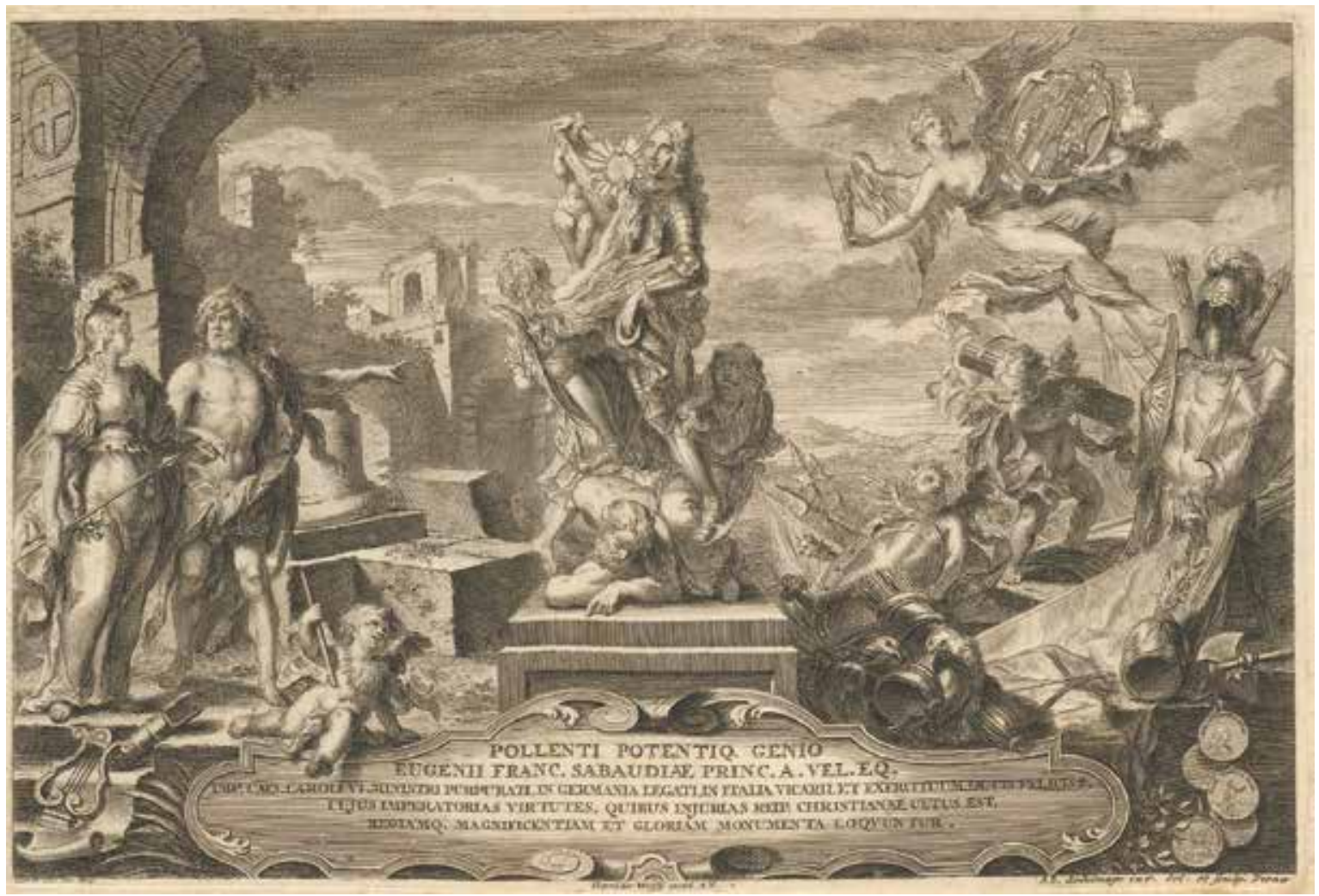

14. Jacob Sedelmayr, Apoteoza Eugena Savojskog, bakrorez u: Salomon Kleiner, Residences Memorables De l'incomparable Heros de nôtre Siecle ou Representation exacte des Edifices et Jardins de Son Altesse Serenissime Monseigneur Le Prince Eugene Francois Duc de Savoye et de Piemont (...), Augsburg, 1731., Beč, Österreichische Nationalbibliothek

Jacob Sedelmayr, Apotheosis of Eugene of Savoy, copperplate engraving in: Salomon Kleiner, Residences Memorables De l'incomparable Heros de nôtre Siecle ou Representation exacte des Edifices et Jardins de Son Altesse Serenissime Monseigneur Le Prince Eugene Francois Duc de Savoye et de Piemont (...), Augsburg, 1731, Vienna, Österreichische Nationalbibliothek

Car Karlo VI. imenovao je princa Eugena 1724. godine carskim namjesnikom (generalnim vikarom austrijskih posjeda) u Italiji. ${ }^{42}$ Radilo se o uglednom, visoko dotiranom naslovu bez zaduženja i obveza. U spomen tom događaju emitirana je medalja Benedikta Richtera (sl. 13) na kojoj se carev namjesnik ikonografski izjednačava s Herkulom antičkim polubožanstvom omiljenim u carskoj ikonografiji njegova doba. ${ }^{43} \mathrm{~S}$ Herkulom se na medaljama (i inače $\mathrm{u}$ prikazbenim umjetnostima) osobito često poistovjećuju i Leopold I. i Karlo VI. ${ }^{44}$ Josip I. prikazan je na medalji kovanoj prigodom osvajanja tvrđave Mons na sjeveru Francuske 1709. godine s Marsom i Herkulom na reversu. ${ }^{45}$ Dok je natpisom na aversu Princ Eugen tituliran kao namjesnik Italije, natpis straga, iznad lika Herkula, oslonjenog na čvorovitu toljagu, ukazuje na njegove uspjehe kako u ratu tako i u miru (Et pace et bello). I taj obrazac prisvojen je za Eugena iz vladarske ikonografije, tj. iz promidžbe monarha kao dobroga, uspješnog i sretnog vladara kako u mirnim tako i u ratnim vremenima. ${ }^{46}$ Ovdje se njegovo značenje odnosi na Eugenovo osvajanje sjeverne Italije, nakon kojeg slijedi uspješno upravljanje u službi careva namjesnika.

Naravno, kako je već naznačeno, u mnogo većem i reprezentativnijem opsegu ikonografija Herkula ugrađena je u vizualne programe Eugenovih građevina, posebice dvorca Belevedere i njegove zimske palače u Himmelpfortgasse u Beču.$^{47}$ Uključivanje antičkih heroja u promidžbeni program velikog vojskovođe dosiže vrhunac na bakroreznoj tabli - alegorijskoj naslovnici prvog sveska znamenitog djela Salomona Kleinera o dvorcu Belvedere, koje je u deset svezaka objavljeno u Augsburgu između 1731. i 1734. godine ${ }^{48} \mathrm{U}$ središtu teatralne kompozicije (sl. 14) smještena je znamenita skulptura apoteoze Eugena Savojskog koju je 1718. - 1720. izradio Balthasar Permoser. Slijeva prilaze joj Minerva i Herkul koji rukom pokazuje na Eugena. Muze s prije spomenute Mandacherove "medalje" ovdje je zamijenila Minerva s atributima lire, knjige i svitka kao medijima kojima se slavi Eugen. Na desnoj strani, krcatoj atributima vojničke slave, prikazane su i medalje kao neizostavne nositeljice i širiteljice vizualne memorije i trijumfa nepobjedivoga vojskovođe.

\section{Gladius Gideonis - Eu-genius}

Poistovjećivanje s biblijskim tipovima, posebice starozavjetnim izraelskim junacima, poput Gideona i Jošue, ubraja se među omiljene retoričke figure namijenjene veličanju pobjednika u bitkama protiv nadmoćnijih neprijatelja, naročito ako se radi o neprijateljima kršćanstva. Na jednoj medalji Johanna Jakoba Wolraba kovanoj u povodu oslobađanja 

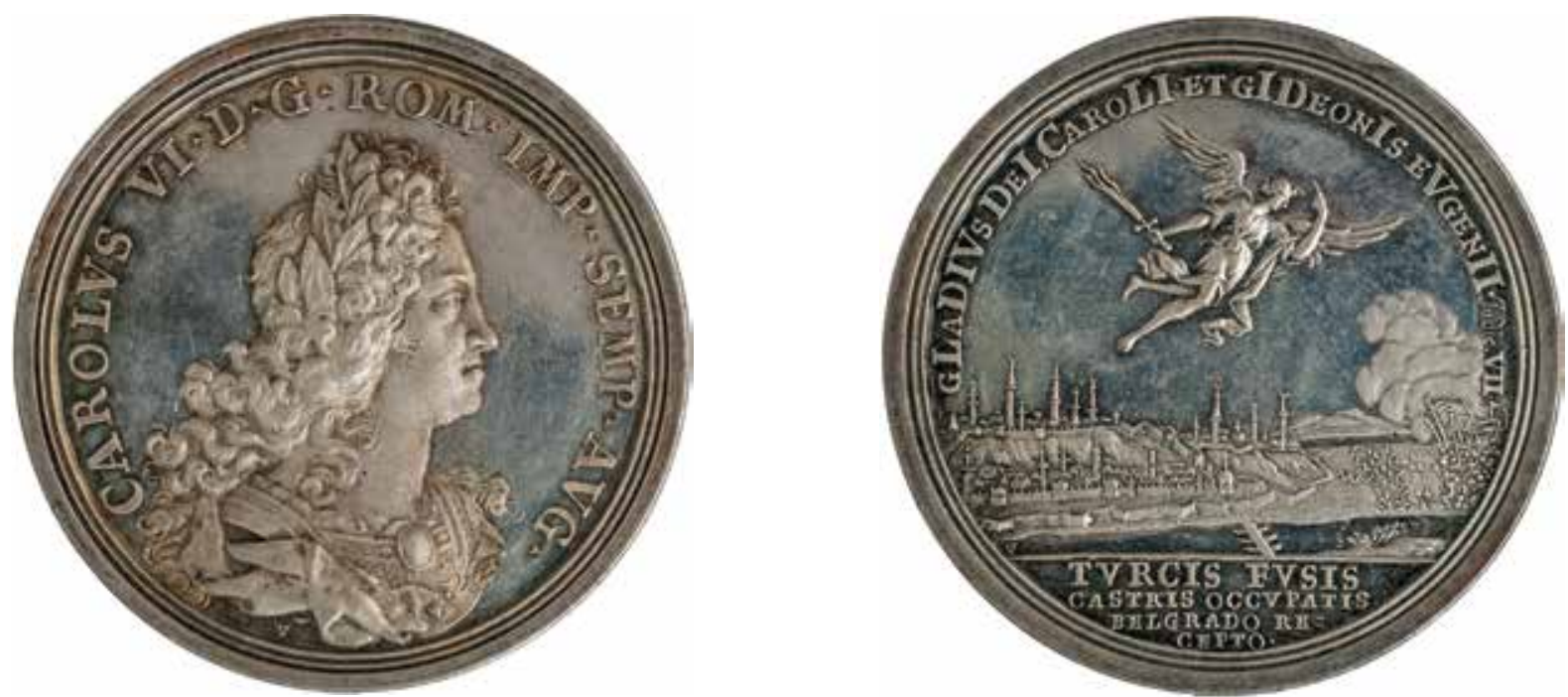

15. Georg Wilhelm Vestner, medalja uz osvajanje Beograda, 1717., Zagreb, Arheološki muzej, inv. br. 7468 Georg Wilhelm Vestner, medal commemorating the conquest of Belgrade, 1717, Zagreb, Archaeological Museum, inv. No. 7468

16. Georg Wilhelm Vestner, medalja uz osvajanje Beograda, 1717., Muzej Slavonije Osijek, inv. br. 4838

Georg Wilhelm Vestner, medal commemorating the conquest of Belgrade, 1717, Osijek, Museum of Slavonia, Inv. No. 4838

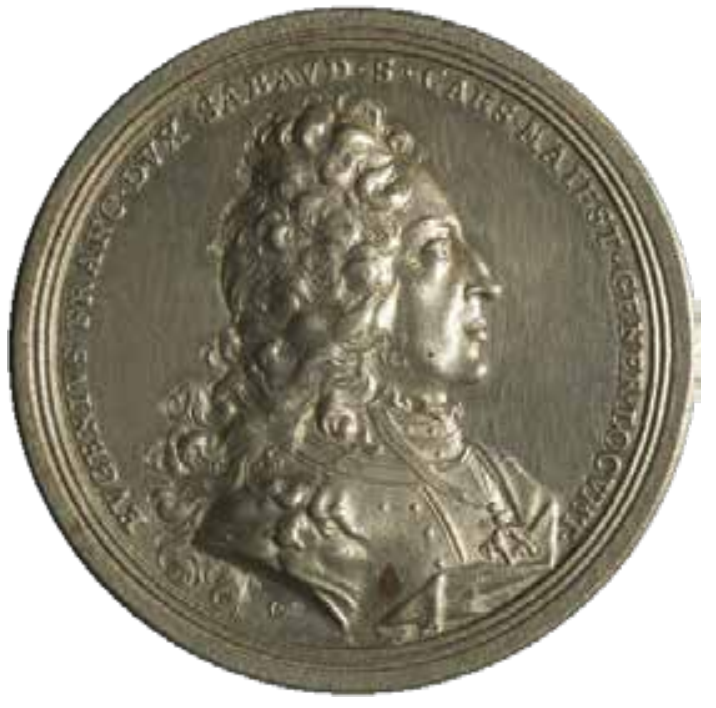

Budima od Turaka u rujnu 1686. car Leopold I. prikazan je u ovjenčanom poprsju na prednjoj strani iznad vedute osvojenoga grada. ${ }^{49} \mathrm{Na}$ reversu on je izjednačen s uspravnim Jošuom koji u punoj ratnoj spremi zapovjedničkom palicom zaustavlja sunce. Iza njega mjesec pada s neba, dok u pozadini bijesni bitka. Simbolička iluzija odnosi se na Leopoldovu istodobnu nadmoć nad francuskim kraljem sunca, Ljudevitom XIV. i nad osmanlijskom silom koju simbolizira mjesec, a s kojom je paktirao francuski kralj.

Iznenađujuće sretna, prema nekima hazarderska, pobjeda nad mnogo nadmoćnijom osmanskom vojskom u bitci kod Beograda 1717. dala je povoda identifikaciji Eugena Savojskog s biblijskim Gideonom. Gideon je uz Jahvinu pomoć s malim brojem izabranih vojnika pobijedio brojčano nadmoćne Midjance koji su se u panici razbježali i svoj tabor prepustili Izraelcima. Jednako tako Eugen je pod Beogradom pobijedio brojčano nadmoćnije Turke i osvojio njihov tabor. U suvremenoj interpretaciji navodi

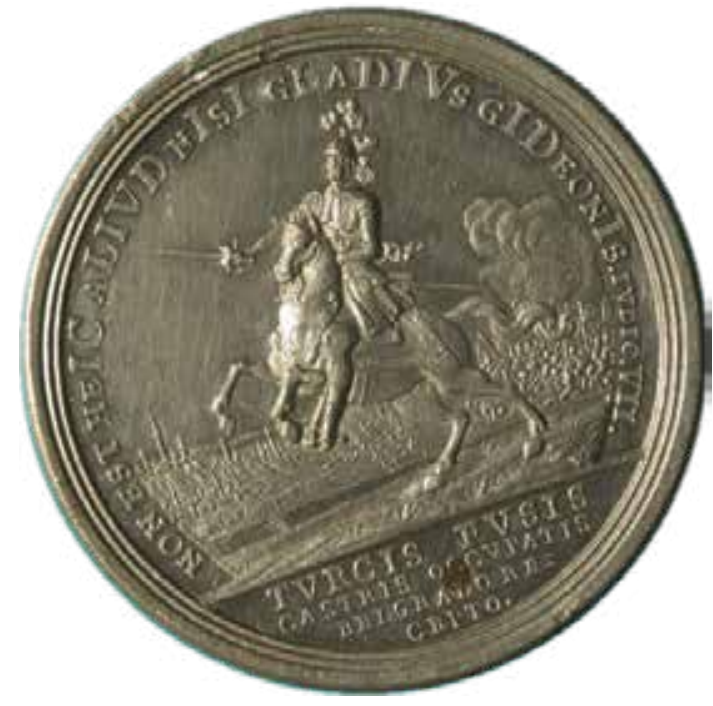

se etimologija hebrejskog imena Gideona kao »onaj koji je sasjekao", što je Eugen učinio s neprijateljima kršćanstva. ${ }^{50}$ Na medalji Georga Wilhelma Vestnera (sl. 15) provedeno je trostruko simboličko izjednačavanje: na aversu prikazan je sprijeda Karlo VI., dok poleđinu medalje zauzima veduta Beograda nad kojom lebdi anđeo s plamenim mačem. ${ }^{51}$ Natpis Gladius Dei Caroli et Gideonis Eugenii. Judic. VII. (Mač Božji, Karlov i Gideona Eugena, Knjiga sudaca VII, kronogram 1717.) parafraza je biblijskih riječi Gladius Domini et Gideonis, čije prošireno značenje osim Boga i Gideona (Eugena) obuhvaća i ulogu cara: iza mača kojim su sasječeni i uništeni neprijatelji vjere stoje Bog, car i princ Eugen. Anđeo s ognjenim mačem nad gradom i bojištem aluzija je na Božjeg anđela koji se objavio Gideonu pozivajući ga da s Jahvinom pomoći oslobodi Izraelce. Kao što se mač Gideonov u biblijskom tekstu navodi kao znamen poraza midjanske vojske, tako je Eugen simbolički stiliziran u izvršitelja Božje i careve volje, a time i u operativnu ratničku 

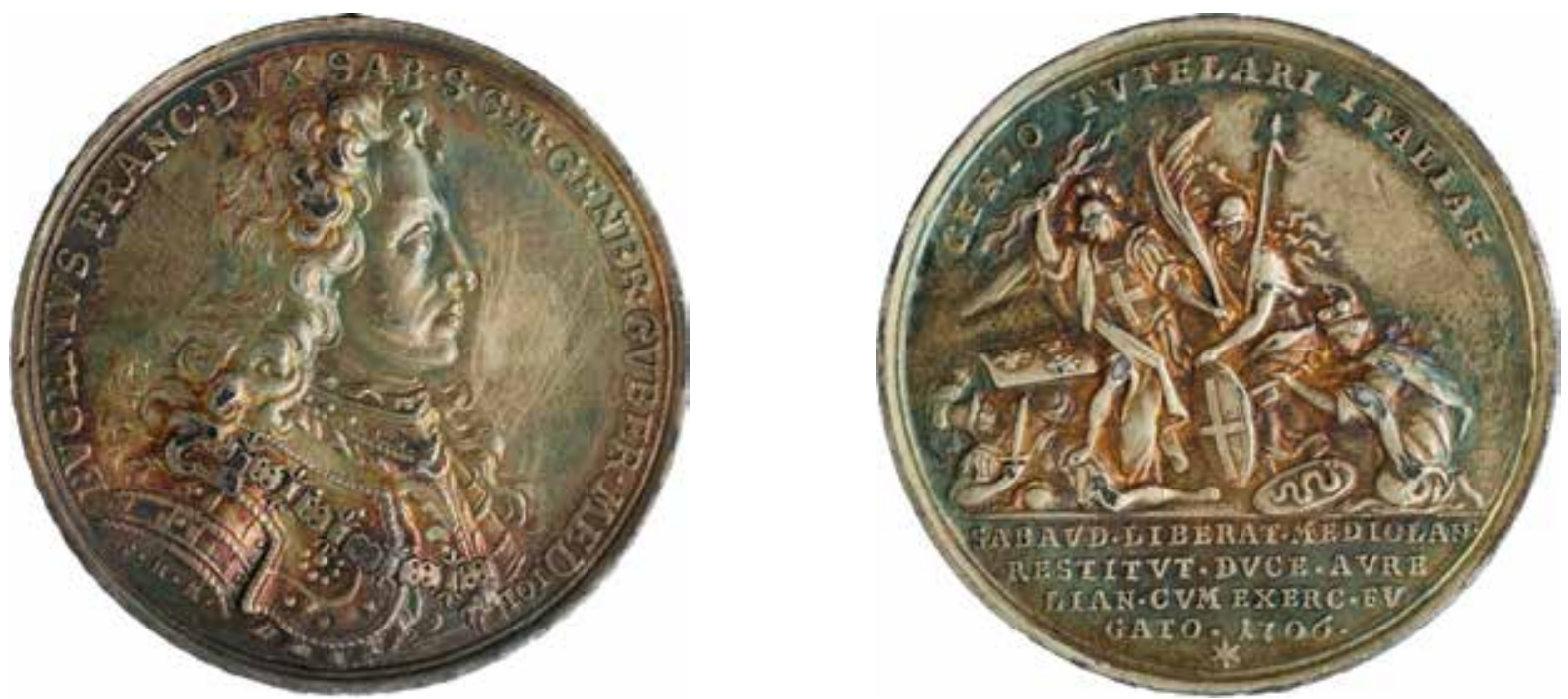

17. Philipp Heinrich Müller, medalja u povodu Eugenova imenovanja za guvernera Milanskog vojvodstva, 1706., Zagreb, Arheološki muzej, inv. br. 7621

Philipp Heinrich Müller, medal on the occasion of Eugene's appointment as Governor of the Duchy of Milan, 1706, Zagreb, Archaeological Museum, Inv. No. 7621

ruku nebeske i zemaljske pravde. Tako se i na medaljama Eugena Savojskog instrumentalizacijom biblijske tipologije manifestira "teološko" tumačenje povijesnog događaja koji se realizira u skladu s odlukama Božje providnosti i kao rezultat Božje intervencije. ${ }^{52} \mathrm{Na}$ drugoj medalji Georga Wilhelma Vestnera uz osvajanje Beograda (sl. 16) avers donosi poprsje princa Eugena, dok je na reversu Eugen još jednom prikazan na konju u ratnom oklopu, s ispruženim mačem u desnoj ruci i vedutom grada s bitkom u pozadini. ${ }^{53}$ Natpis ga i ovdje povezuje s Gideonom: Non est heic aliud nisi Gladius Gideonis. Iudic(um). VII. (Nije to drugo nego mač Gideonov).

Igre riječi, etimološke asocijacije, posizanje za anagramskim pretvorbama imena - sve su to literarne figure koje se u baroknoj vizualnoj komunikaciji pretvaraju u simbole, personifikacije i alegorije dobro poznate sudionicima u komunikaciji. ${ }^{54}$ Mnogi su motivi bili prepoznatljivi na razini konvencionalnih kodova, za druge je trebalo dodatno objašnjenje. Motiv Viktorije s palmom u ruci bio je dobro poznat suvremenicima, jednako kao i simboličko označavanje Francuske burbonskim ljiljanima ili galskim pijetlovima. No u mnogim slučajevima "hijeroglifske figure" na medaljama, kao i njihovi prateći natpisi, tražile su dodatna objašnjenja, koja su se mogla naći u odgovarajućim numizmatičkim priručnicima ${ }^{55}$ Latinski oblik Eugenova imena sadrži riječ genius koja se tumačila kao dobri duh ili anđeo zaštitnik. ${ }^{56}$ Njezinu konverziju u vizualni znak donosi revers medalje Philippa Heinricha Müllera (sl. 17) u povodu Eugenovih pobjeda nad Francuzima u Italiji i njegova imenovanja za guvernera Milanskog vojvodstva 1706. godine. ${ }^{57}$ Dok je na aversu medalje prikazano njegovo poprsje s dugačkom allonge-perikom i odgovarajućim natpisom, na stražnjoj strani vojskovođa se pojavljuje kao krilati ratnik sa svežnjem munja u desnici i palminom granom pobjede u lijevoj ruci. Na prsnom oklopu ima veliki savojski križ koji se još jednom ponavlja na štitu žene - ratnice i personifikacije Savoje, koja mu se pridružuje u borbi. Njihov je bijes usmjeren prema neprijatelju koji pada i brani se štitom s burbonskim ljiljanima. Njemu nasuprot kleči personifikacija grada Milana sa svojim štitom, držeći u ruci veliki ključ grada. Iznad je latinski natpis Genio tutelari Italiae (Duhu zaštitniku Italije), a pri dnu medalje drugi natpis komemorira povod njezina nastanka. Svi su vizualni detalji njemačkim čitaocima precizno objašnjeni u već spomenutoj numizmatičkoj biografiji Eugena Savojskog objavljenoj 1736. pod naslovom Eugenius nummis illustratus. ${ }^{58} \mathrm{U}$ njoj su prevedeni i latinski natpisi koje slabije obrazovani primatelji zasigurno ne bi razumjeli, jednako kao i natpis na obodu medalje, koji potječe iz Eneide (12, 367-8): Quacumque viam secat, agmina cedunt, conversaeque ruunt acies... Stih antičkog epa opisuje bijesnoga rutulskog kralja Turna kako u borbi protiv Trojanaca sebi krči put kroz gomile vojnika koji u panici padaju pod njegovim mačem. ${ }^{59}$ Mentalna slika pobuđena tim citatom priziva upornost i ratne uspjehe princa Eugena koji u svom prodoru preko sjeverne Italije dolazi do Milana i oslobađa svoju domovinu Savoju.

Kao anđeo zaštitnik Eugen se pojavljuje i na jednoj medalji Philippa Heinricha Müllera (sl. 18) kovanoj u povodu epohalne pobjede kod Höchstädta 1704 . godine ${ }^{60} \mathrm{U}$ toj znamenitoj bitci, jednoj od najvećih u Ratu za španjolsko nasljedstvo, Eugen Savojski je sa svojim engleskim saveznikom Johnom Churchillom, vojvodom od Marlborougha, pobijedio udruženu francusku i bavarsku vojsku između Höchstädta i Blindheima na Dunavu. U bitci je zarobljen francuski zapovjednik maršal Tallard. Nakon bitke čitava je južna Njemačka došla pod vlast Habsburga, a nekadašnji carev saveznik, izborni knez Maksimilijan Emanuel Bavarski, koji je prešao na stranu Francuza, morao je u progonstvo. ${ }^{61} \mathrm{Na}$ aversu medalje prikazano je poprsje princa Eugena, dok je na stražnjoj strani otvorena panorama neprijateljskog tabora 

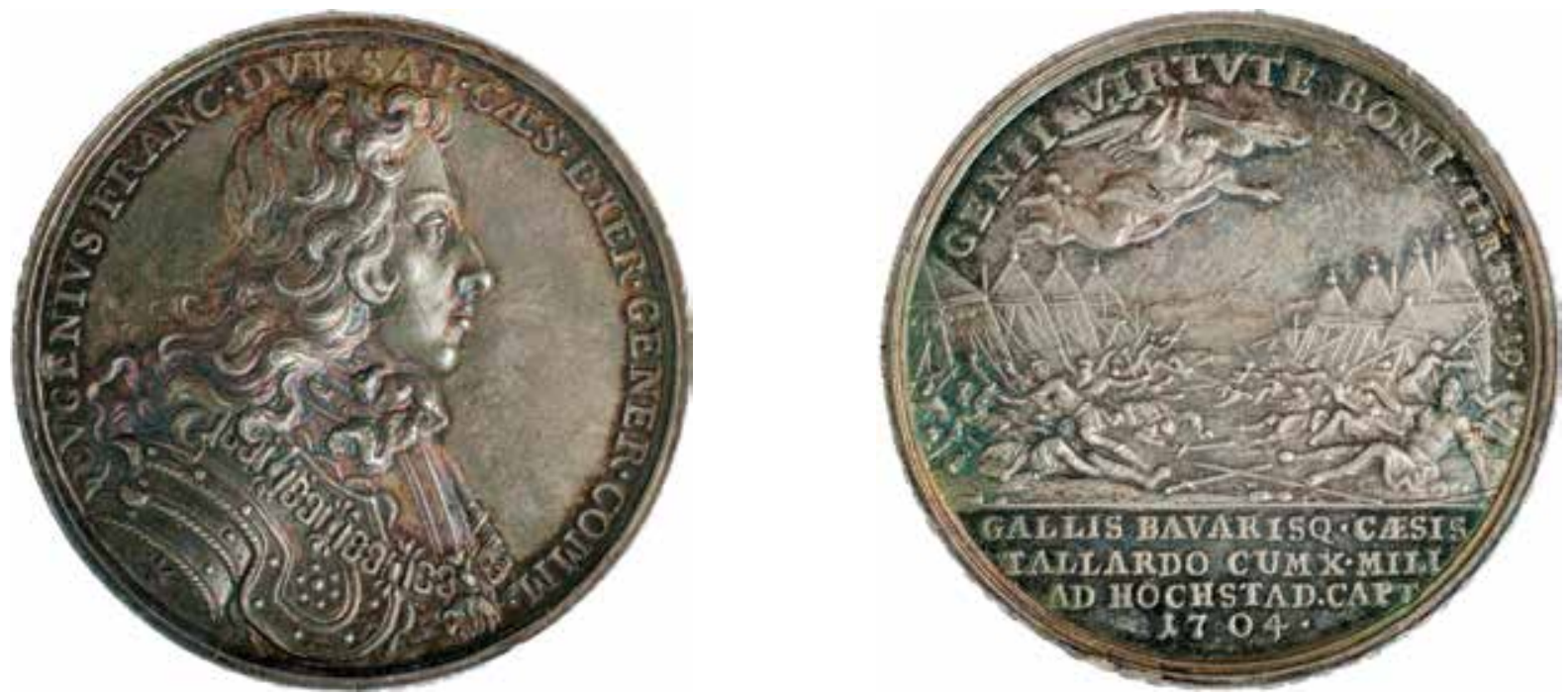

18. Philipp Heinrich Müller, medalja uz bitku kod Höchstädta, 1704., Zagreb, Arheološki muzej, inv. br. 7620

Philipp Heinrich Müller, medal commemorating the Battle of Höchstädt, 1704, Zagreb, Archaeological Museum, Inv. No. 7620

s popadalim i mrtvim vojnicima, nad kojima lebdi anđeo zaštitnik s plamenim mačem. Natpis straga: Genii virtute boni (Snagom dobrog anđela, Druga knjiga o kraljevima 19, 35) povezuje prizor sa starozavjetnim događajem u kojem je Jahvin anđeo pomogao Izralecima u borbi protiv Asiraca pobivši u njihovu taboru 185 tisuća ljudi. Snaga dobrog anđela i Gideonov mač metonimijske su figure kojima se princ Eugen kao vojskovođa stavlja u posvećenu predaju pravedne borbe protiv neprijatelja pod Božjom zaštitom. Semantički raspon poruke u političkom je smislu proširen natpisom na obodu medalje: Gloria ad Tibiscum Hungariae parta, renovatur ad Danubium Germaniae (Slava rođena na Tisi u Ugarskoj obnovljena je na njemačkom Dunavu). Dakle, sedam godina nakon pobjede kod Sente medalja ističe Eugenovu presudnu ulogu u borbi Carstva protiv neprijatelja na dvije fronte: Osmanlija na istoku i Francuza sa saveznicima na zapadu.

\section{Posmrtna apoteoza}

Eugen Savojski preminuo je blagom smrću 21. travnja 1736. godine u svojoj zimskoj palači u Himmelpfortgasse u Beču u dobi od 73 godine. Za pogrebnu ceremoniju slavnom je vojskovođi po naredbi cara Karla VI. njegov omiljeni arhitekt Lukas von Hildebrandt u bečkoj katedrali podigao velebni castrum doloris, visok 22 metra, na čijem je vrhu postavljena konjanička figura princa Eugena u odjeći rimskog vojskovođe. Nad njegovom glavom lebdio je genij s krunom vječnosti. ${ }^{62}$ Mitološka simbolika vojskovođe i njegovih pobjeda koje jamče besmrtnost njegovu imenu, dosegla je svojevrsni apogej na njegovim posmrtnim medaljama. ${ }^{63} \mathrm{Na}$ njima se još jednom pojavljuju motivi koje smo susretali na medaljama emitiranim za Eugenova života. Tako je na medalji Georga Wilhelma Vestnera (sl. 19) prikazan sarkofag u kojem počiva
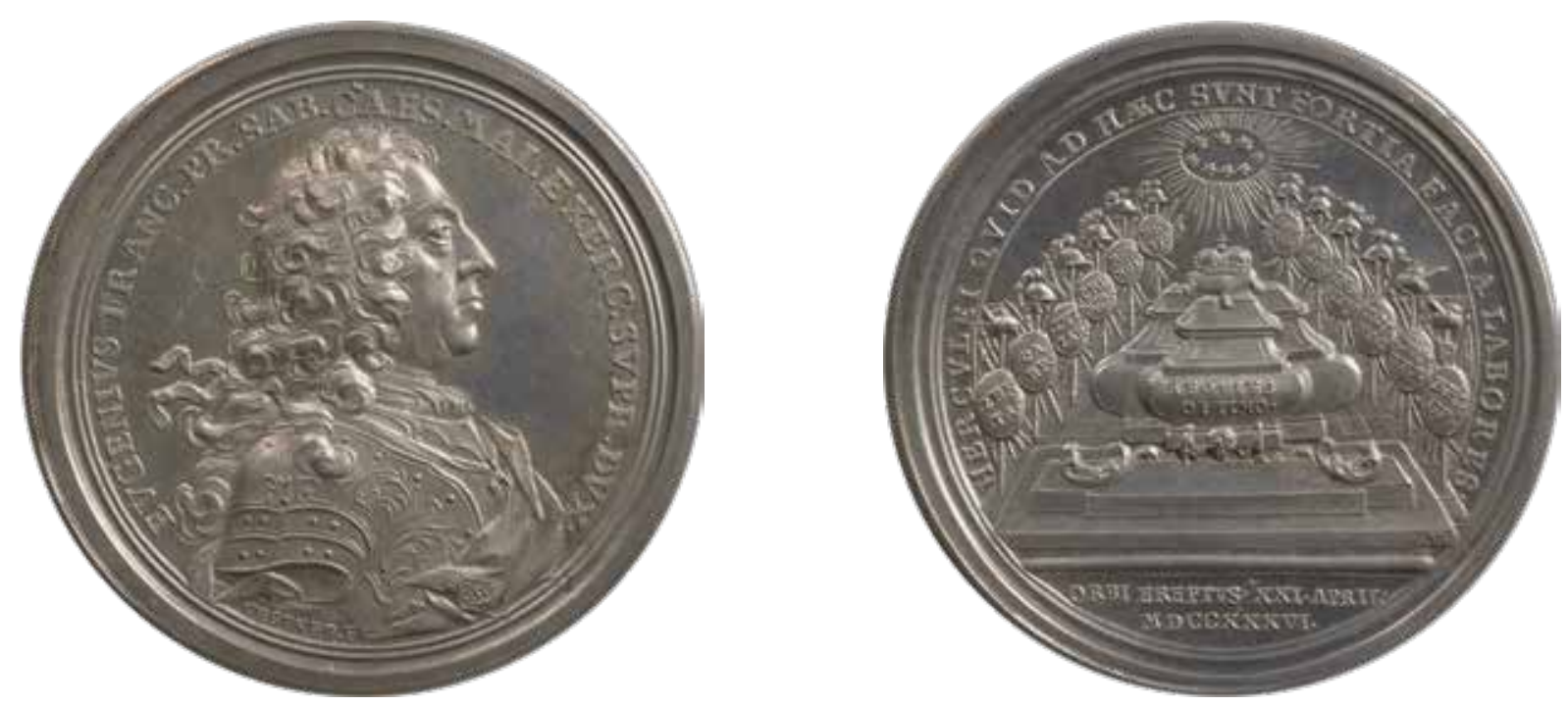

19. Georg Wilhelm Vestner, posmrtna medalja Eugena Savojskog, 1736., Beč, Kunsthistorisches Museum, Inv. Nr. 6516bß Georg Wilhelm Vestner, posthumous medal of Eugene of Savoy, 1736, Vienna, Kunsthistorisches Museum, Inv. No. 6516bß 

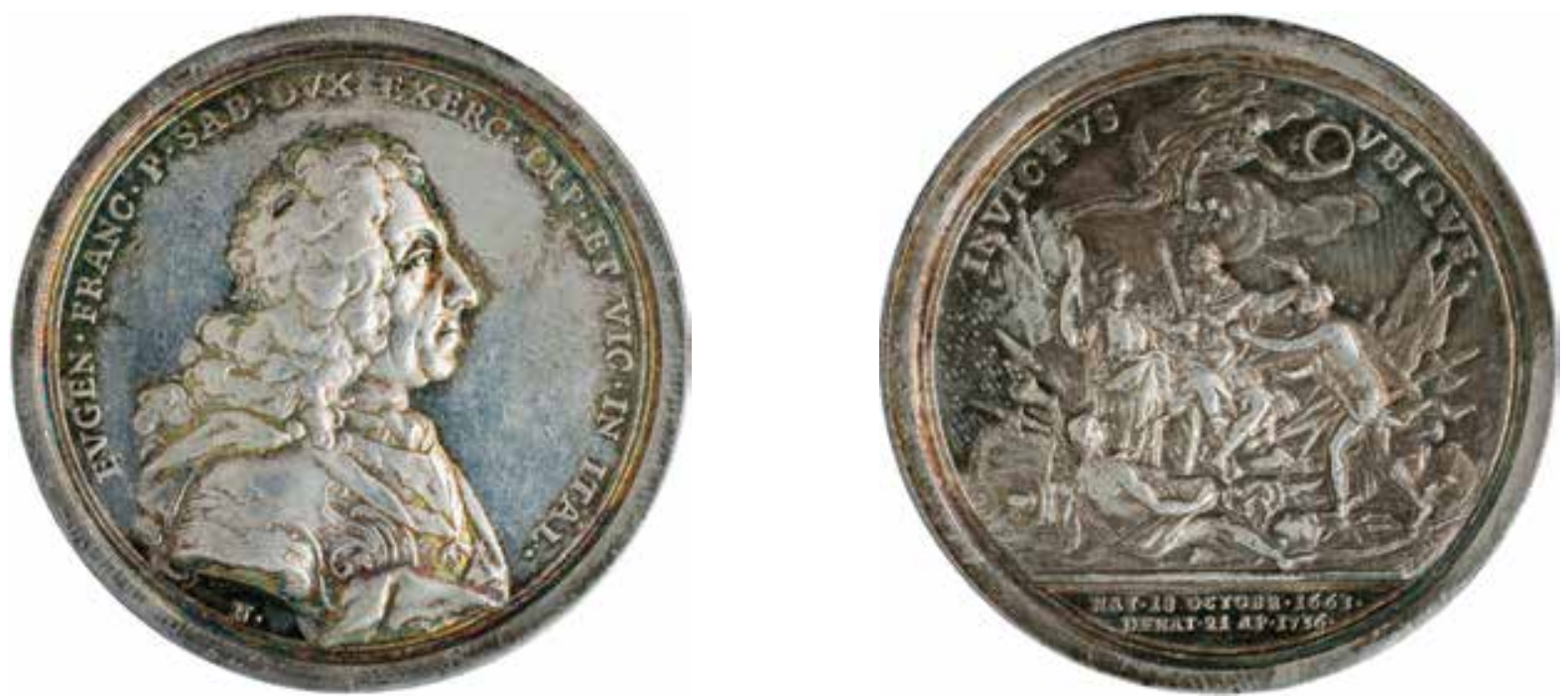

20. Paul Gottlieb Nürnberger, posmrtna medalja Eugena Savojskog, 1736., Zagreb, Arheološki muzej, inv. br. 7623

Paul Gottlieb Nürnberger, posthumous medal of Eugene of Savoy, 1736, Zagreb, Archaeological Museum, Inv. No. 7623

princ Eugen s natpisom Requies optimo (Mir za najizvrsnijega), dok je s jedne i s druge strane sarkofaga nanizano po šest štitova s imenima mjesta na kojima je Eugen izvojevao svoje najveće pobjede. ${ }^{64}$ Dvanaest izabranih bitaka odgovara broju Herkulovih pothvata, dok natpis na obodu retorički postavlja pitanje: »Što su Herkulovi pothvati prema ovim hrabrim djelima? « Herkul je, dakle, još jednom iskorišten kao uvriježeni antički mitopoetski topos u posmrtnom veličanju suvremenog vojskovođe.

Isto bi se moglo reći i za motive na medalji Paula Gottlieba Nürnbergera (sl. 20) s natpisom Invictus ubique (Posvuda nepobjediv). ${ }^{65}$ Dok je na licu medalje uobičajeno portretno poprsje Eugena Savojskog, na njezinom naličju autor je osmislio malu alegorijsku predstavu u čijem je središtu princ Eugen kao bog rata na prijestolju podignutom na ratnim trofejima. Prilazi mu božica sretnog trenutka, koju je princ zgrabio za čuperak, desno mu je razboritost (u ruci drži luč) na koju se princ oslanja, u podnožju leži personifikacija sreće i obilja, koja iz svojega roga sipa lovorove vijence, iznad glave mu lebdi genij neprolazne slave prinoseći zvjezdanu krunu u jednoj, a znak vječnosti - zmiju koja grize vlastiti rep - u drugoj ruci.

Peter Paul Werner modelirao je u povodu komemoracije princa Eugena medalju s jednim od njegovih najvjernijih i najdojmljivijih medaljonskih portreta kojim je vojskovođa okrenut gotovo sučelno prema promatraču. ${ }^{66}$ Njegova pojava sugerira živu neposrednost i toplinu koja se ne može postići na čistim profilnim portretima ${ }^{67}$ Idealizirano produhovljeni izraz Eugenova lica odgovara njegovu položaju na stražnjoj strani medalje. Eugen je prikazan kao usnuli ratnik, naslo-
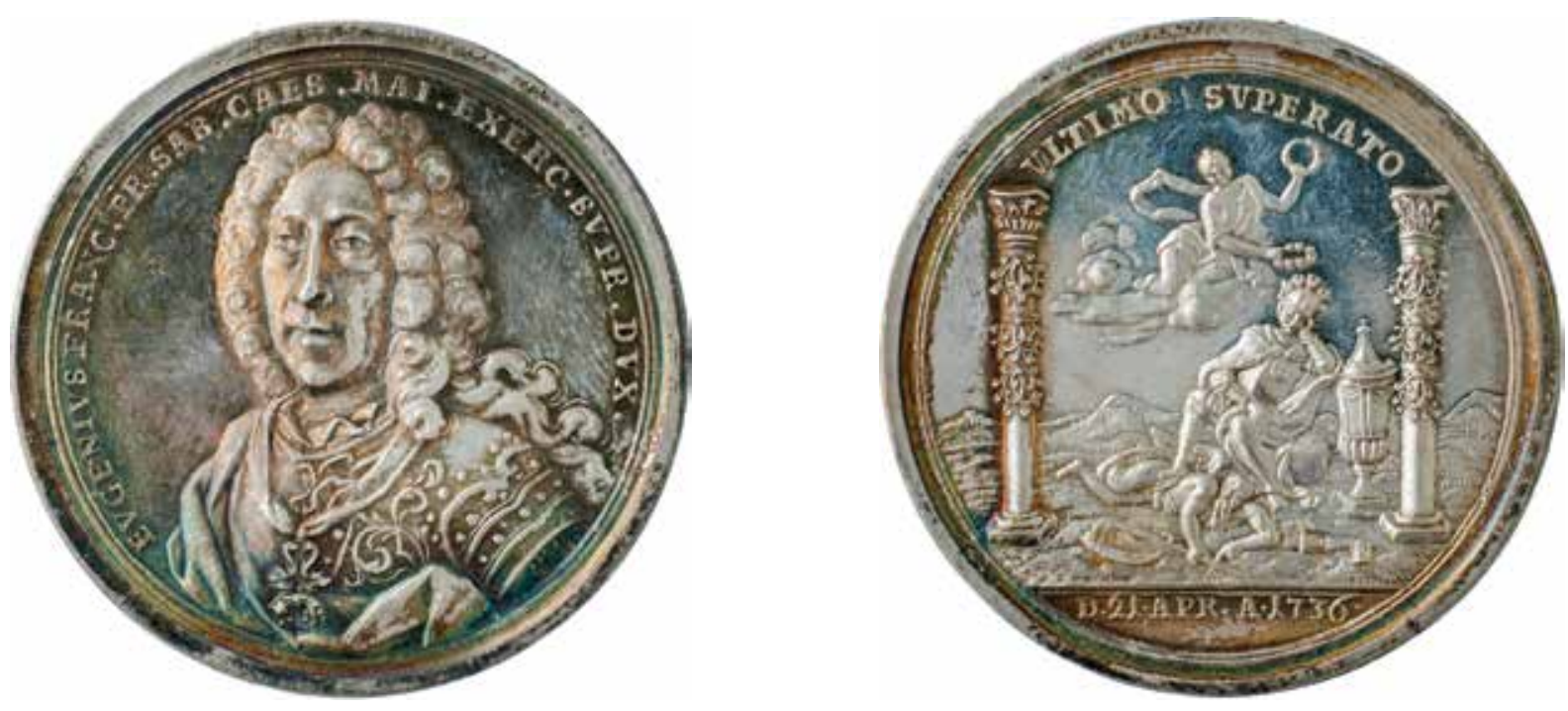

21. Peter Paul Werner, posmrtna medalja Eugena Savojskog, 1736., Zagreb, Arheološki muzej, inv. br. 7624

Peter Paul Werner, posthumous medal of Eugene of Savoy, 1736, Zagreb, Archaeological Museum, Inv. No. 7624 
njen na urnu, pod nogama mu personifikacija vremena u liku krilatog starca sa slomljenom kosom i izvrnutim pješčanim satom. Napis Ultimo superato (Nakon što je pobijeđen i posljednji neprijatelj) aludira na pobjedu nad vremenom, tj. na besmrtnost. Gaženje personificirane prolaznosti također je jedan od vizualnih motiva preuzet iz antičkog nasljeđa. Motiv pogaženog neprijatelja (calcatio) obično se rabi u prikazivanju poraženih protivnika, osobito barbara i krvoločnih divljaka ${ }^{68}$ Umjetnik ga je ovdje iskoristio kao uvriježenu retoričku figuru koja odgovara simboličkom naslovu medalje, asocirajući ujedno na prinčeve pobjede nad Osmanlijama. Lijevo i desno diže se po jedan stup sa po šest lovorovih vijenaca - svaki označava pobjedu u nekoj od velikih bitaka, s aluzijom - jednako kao i na opisanoj medalji G. W. Vestnera - na 12 Herkulovih pothvata. Lebdeći na oblaku, genij besmrtnosti polaže na Eugenovu glavu zvjezdani vijenac neprolazne slave, dok u drugoj ruci drži simbol vječnosti - zmiju koja grize vlastiti rep.

Ikonografska analiza medalja Eugena Savojskog upućuje na zaokružen mitopoetski program koji se ostvaruje putem uvriježenih mehanizama barokne vizualne propagande: obi- latim korištenjem izražajnih sredstava portretne, mitološke, biblijske, amblemske i povijesno-topografske provenijencije. Medalja je sama po sebi kombinirani medij koji računa s udruženim djelovanjem slike i teksta, prikaza i natpisa. Bitan je čimbenik njezina vizualnoga, reprezentacijskog i propagandnog djelovanja portret slavljene osobe s kojim se asocijativno povezuju simbolički, alegorijski, povijesnonarativni i drugi vizualni kodovi. Natpisi proširuju njihove konotacije služeći ujedno, kako je to pokazao R. Barthes, kao značenjska sidra za njihovu usmjerenu interpretaciju. ${ }^{69}$ Na medaljama Eugena Savojskog koncentrirane su dvije dominantne značajke kojima se opća mjesta baroknoga retoričkog repertoara individualiziraju i prilagođavaju njegovoj golemoj ulozi u političkoj areni vremena. Gledano u cjelini, u oči ponajprije upada vojnički karakter njegova numizmatičkog profila iskovan u borbama na dvije fronte protiv Francuske i njezinih saveznika u Ratu za španjolsko nasljedstvo i protiv Osmanlija u ratu za oslobađanje Ugarske. Druga je važna značajka Eugenova numizmatičkog imagea, koja se čvrsto sjedinjuje s prvom, isticanje njegovih zasluga za monarhiju, kojoj je vjerno i predano služio u ratu i u miru tijekom svoje duge vojničke i diplomatske karijere. Možda više nego u drugim vizualnim medijima Eugen je upravo na medaljama stiliziran kao utilissimus Reipublicae princeps,$^{70}$ kao produžena vojnička ruka triju careva i kao njihov alter ego u borbi za interese Carstva.

\section{Bilješke}

* Ovaj rad nastao je u sklopu istraživanja na znanstvenom projektu Eugen Savojski (1663. - 1736.) i gradovi-tvrđave jugoistočne granice Habsburške Monarhije (HRZZ-IP-2018-01-3844), koji financira Hrvatska zaklada za znanost.

\section{1}

Usp. LISELOTTE POPELKA, Die barocke Medaille als Massenmedium, Mitteilungen der Gesellschaft für vergleichende Kunstforschung in Wien, 40 (1988.), 7-9; WERNER TELESKO, Die habsburgischen 'Türkenmedaillen' des 17. und frühen 18. Jahrhunderts. Historische Gedächtissetzung als Form monarchischer Repräsentation, u: Johannes Feichtinger - Johann Heiss (ur.), Geschichtspolitik und »Türkenbelagerung«. Kritische Studien zur »Türkenbelagerung«, Band 1, Wien, 2013., 143-166.

\section{2}

Najvažnije su izložbe i katalozi sljedeći (kronološkim redom): IVAN MIRNIK, Turski ratovi na medaljama, Zagreb, 1979.; Od svagdana do blagdana. Barok u Hrvatskoj, katalog izložbe, Zagreb, 1993.; HERMINE GÖRICKE-LUKIĆ, Medalje i plakete iz zbirke muzeja Slavonije Osijek 15. - 20. stoljeće, Osijek, 1993.; DUBRAVKA PEIĆČALDAROVIĆ, Slike mira: oživljena Hrvatska u vrijeme Karlovačkog mira 1699., Zagreb, 1999.

\section{3}

O tome usp. WERNER TELESKO, Aeternitas Augustae. Zur Ikonographie Maria Theresias, u: Sabine Haag (ur.), Zuhanden Ihrer Majestät. Medaillen Maria Theresias, Wien, 2017., 37-43, osobito 42.

\section{4}

MARK JONES, The medal as an instrument of propaganda in late 17th and early 18th century Europe, The Numismatic Chronicle, 142 (1982.), 117-126, posebice 118.

\section{5}

Usp. YLVA HAIDENTHALLER, A different rhetoric. The usage of medals as political art, u: Ludwig Qvarnström (ur.), Swedish Art History. A Selection of Introductory Texts, Lund, 2018., 117-126, 117-118. Autorica nabraja najvažnije prednosti medalja: »Medals had the advantage that they were portable, a monument in a convenient size. Further, they were easy to produce but they still had this aura of extravagance. In contrast to engravings, medals were cast for posterity. They should endure over time. In that regard, medal art is truly a product of its time. It is a fusion of the Baroque age's preference for luxury objects and collectable items at the same time as it combines visual communication with emblematic riddles, allegories, and Latin proverbs. They connect 
not only humans, but due to their persistent and widely appreciated material even time and space.«(126).

6

Tako ih označava STEPHEN K. SCHER, The currency of fame: Portrait medals of the Renaissance, New York, 1994.

7

Eugenius nummis illustratus. Leben und Thaten des Grosen und Siegreichen Printzen Eugenii: worinnen dessen grose Kriege, Siege, und Helden-Thaten, biß an sein Ende, aus bewährten Urkunden und Nachrichten mit unpartheyischer Feder entworffen, und durch die darauf geprägte Müntzen erläutert werden, izd. Johann Adam Schmidt, Nürnberg, 1736., 4 verso. Predgovor je datiran u Beču, 11. rujna 1736., autor nije potpisan. O knjizi vidjeti: LISELOTTE POPELKA, Eugenius in Nummis. Kriegs-und Friedenstaten des Prinzen Eugen in der Medaille, Wien, 1986., br. 255.

8

EUGEN VICTOR MANDACHER, Acta serenissimi principis Eugenii Francisci Sabaudiae et Pedemontij Ducis sub ternis augustissimis Romanis Imperatoribus Leopoldo, Josepho et Carolo, eidem serenissimo principe humilissime consecrata, a (...) Eugenio Victore à Mandacher (...), Viennae Austriae, Gregorius Kurtzböck, 1735. Za opis Mandacherove knjige v. LISELOTTE POPELKA (bilj. 7), br. 13. Na početku knjige umetnuta je presavijena tabla s Eugenovim konjaničkim portretom.

9

Sličnu je disertaciju objavio grof Michael-Hermann Joseph Althann (1689.) s tezama i amblemima posvećenim vojnim uspjesima cara Leopolda I. u Ugarskoj. Usp. MILAN PELC, Panegyric Emblem Books, Jesuits and the Habsburg Emperors: Some Examples Related to 17th-Century Croatia, Radovi Instituta za povijest umjetnosti, 43 (2019.), 59-74.

10

LISELOTTE POPELKA (bilj. 7), 14.

11

Usp. građu u katalogu LISELOTTE POPELKA (bilj. 7). Interes samoga princa Eugena za medalje bio je velik. Osim značajne zbirke medalja posjedovao je i opsežnu stručnu literaturu o njima. Usp. LISELOTTE POPELKA (bilj. 7), XI.

12

EUGEN VICTOR MANDACHER (bilj. 8), 133.

13

EUGEN VICTOR MANDACHER (bilj. 8), 135.

14

FRANCISCUS PEIKHART, Lob- und Trauer-Rede über den Todt des durchleuchtigen Printzen Eugenii Francisci, Hertzogen von Savoyen und Piemont (...), Wien, 1736.; govor je otisnut u Eugenius nummis illustratus (bilj. 7), 584-638.

15

Usp. WERNER TELESKO (bilj. 1), 143.

16

Usp. PAUL R. SWEET, Prince Eugene of Savoy and Central Europe, American Historical Review, 57 (1951.), 47-62, 48.

17

Primjerice, ispod Eugenova grafičkog portreta umetnutog kao frontispis knjige Eugenius nummis illustratus, Nürnberg, 1736. (bilj. 7). Portret je dao prirediti izdavač knjige J. A. Schmidt prema reprezentativnom bakrorezu koji su u Nürnbergu izradili Andreas i Joseph Schmuzer, a koji ima istu legendu ispod Eugenova lika. Vidi https://research.britishmuseum.org/research/collection_online/ collection_object_details/collection_image_gallery.aspx?assetId $=1613198619$ \&objectId=3749713\&partId=1 (28. travnja 2020.).

18

Carevi Leopold I. i Karlo VI. nisu sudjelovali u vojnim operacijama. Josip I. zapovijedao je opsadom tvrđave Landau 1704. Tim povodom kovana je medalja Ph. H. Müllera u Augsburgu, usp. https:// bawue.museum-digital.de/index.php?t=objekt\&oges=10909 (29. travnja 2020.).

19

Arheološki muzej Zagreb, u daljnjem tekstu AMZ, inv. 7619, primjerak od srebra, 40,5 mm; AMZ, inv. 36458, primjerak od kositra. Opis u: LISELOTTE POPELKA (bilj. 7), br. 81. Opširan opis donosi i Eugenius nummis illustratus (bilj. 7), 169.

20

Preuzet je iz Horacijeve 2. ode - usp. Eugenius nummis illustratus (bilj. 7), 169.

21

Flantibus austris je također motiv iz antičke poezije, tj. iz Vergilija, Eneida, 2. knjiga - usp. Eugenius nummis illustratus (bilj. 7), 169.

22

Motiv iz Vergilija, 10. Ekloga - prema Eugenius nummis illustratus (bilj. 7), 169.

23

Podrugljive alegorije i simboli na račun Francuza pojavljuju se na mnogim medaljama puštenim u optjecaj tijekom Rata za španjolsko nasljedstvo. Primjerice, na jednoj medalji kovanoj uz osvajanje Lillea, kojoj je autor Nicolas Chevalier, prikazan je na aversu carski lav koji je prednjom desnom šapom stao na grb grada Lillea sa znakom ljiljana, a lijevom je zgrabio galskog pijetla koji mu nastoji pobjeći. Usp. NICOLAS CHEVALIER, Relation des campagnes de l'anne 1708 et 1709 avec une explication de toutes les Medailles qu'on a frappees sur ce sujet (etc.), Utrecht, 1710., 33; LISELOTTE POPELKA (bilj. 7), br. 137.

24

Muzej Slavonije Osijek (dalje: MSO), Inv. br. 7184; LISELOTTE POPELKA (bilj. 7), br. 252; HERMINE GÖRICKE-LUKIĆ (bilj. 2), br. 63. Na prednjoj strani medalje prikazan je portret cara Karla VI. Na aversu u prednjem planu vide se laki konjanici (panduri) koji mačevima prijete dobro utvrđenomu francuskom taboru. Ovdje treba napomenuti da se portret cara Karla VI. na aversu osječke medalje razlikuje od onog na medalji iz Beča, koju opisuje LISELOTTE POPELKA (bilj. 7), br. 252. Na osječkoj medalji kao autor portreta signiran je [Benedikt] Richter. Taj isti portret Karla VI. Richter je već upotrijebio na medalji kovanoj u povodu mira u Rastattu 1714. Primjerak te medalje čuva se u Museum für angewandte Kunst, Beč, Inv. br. ME 1214. Vidjeti online: http:// kultur-pool.at/plugins/kulturpool/showitem.action?itemId=10 3079738218\&kupoContext=smartworkDetail (8. srpnja 2020.).

25

AMZ, inv. 7460. IVAN MIRNIK (bilj. 2), br. 189 - to je bakrena inačica medalje koju je u povodu bitke kod Temišvara izradio Martin Brunner s natpisom straga Constantia et fortitudine Caesaris ab Eugenio. - v. LISELOTTE POPELKA (bilj. 7), br. 218. Slično je koncipirana i medalja Georga Wilhelma Vestnera uz opsadu i oslobađanje Temišvara - v. LISELOTTE POPELKA (bilj. 7), br. 217., 
koju također posjeduje AMZ, inv. 7458. Na njoj je tlocrt tvrđave neznatno izmijenjen, natpisi su drugačiji, ističe se oslobađanje Transilvanije.

\section{6}

AMZ, inv. 7475. IVAN MIRNIK (bilj. 2), br. 201; LISELOTTE POPELKA (bilj. 7), br. 230.

27

Prema LISELOTTE POPELKA (bilj. 7), 209. te se varijante čuvaju u Beču, Kunsthistorisches Museum.

28

Usp. KARL GUTKAS, Prinz Eugen von Savoyen, Feldherr und Staatsmann, u: Prinz Eugen und das barocke Österreich, katalog izložbe, Wien, 1986., 19-20, 24-25.

29

LISELOTTE POPELKA (bilj. 7), 74.

30

JEAN DUMONT - JEAN HUCHTENBURGH, Batailles gagnées par le serenissime prince Fr. Eugene De Savoye sur les ennemis de la foi, et sur ceux de l'Empereur \& de L'Empire, en Hongrie, en Italie, en Allemagne \& aux Pais-Bas. Depeintes \& gravées par le Sr. Jean Huchtenburg ... Avec des explications historiques par Mr. J. Du Mont, A La Haye, Pierre Husson, 1720. Drugo izdanje objavljeno je 1725. godine. Grafike su nastale prema velikim slikama koje je J. van Huchtenburgh izradio za princa Eugena. Usp. Prinz Eugen und das barocke Österreich (bilj. 28), br. 8.54 (autor kat. jedinice Karl Gutkas).

\section{1}

AMZ, inv. 7209. IVAN MIRNIK (bilj. 2), br. 162; LISELOTTE POPELKA (bilj. 7), br. 64. Zgodno je napomenuti da se najraniji Eugenov numizmatički portret pojavljuje na drugoj medalji posvećenoj bitci kod Sente, koje su autori Martin Brunner i Georg Friedrich Nürnberger, usp. LISELOTTE POPELKA (bilj. 7), br. 66. EUGEN VICTOR MANDACHER (bilj. 8), 41, bitku kod Sente ilustrira dvjema amblemskim »medaljama «. Na jednoj je prikazan tropej na čijem podnožju piše: Vienna ad Szentam servata (Beč je spašen kod Sente).

\section{2}

Usp. Prinz Eugen und das barocke Österreich (bilj. 28), br. 9, 18 (autor kat. jedinice Helmut Jungwirth). Na sličan način princ Eugen prikazan je na panoramskom prikazu bitke kod Sente Jana van Huchtenburgha, odnosno na njegovim grafikama iz 1720. godine. Usp. DUBRAVKA PEIĆČALDAROVIĆ (bilj. 2), br. 113.

\section{3}

Usp. KARL GUTKAS (bilj. 28), 9. Na sličan se način i pobjeda kod Petrovaradina 5. kolovoza 1717. pripisivala Majci Božjoj Snježnoj. Nakon pobjede Eugen Savojski dao je kod Petrovaradina sagraditi kapelu i za nju je naručio repliku milosne slike Salus Populi Romani (Gospe Snježne) iz Rima. Usp. SANJA CVETNIĆ, Ikonografija nakon Tridentskog sabora i hrvatska likovna baština, Zagreb, 2007., 77.

\section{4}

Eugenius nummis illustratus (bilj. 7), ilustracija uz str. 117. Medalja je zbog upotrijebljenoga biblijskog citata opisana i u enciklopedijskom djelu CHRISTIAN SCHLEGEL, Biblia in nummis, das ist: Kurtzer Entwurff der vornehmsten Biblischen Sprüche \& Historien, die aufMedaillen, Ducaten, Thalern \& andern Müntzen von Königen, Chur- und Fürsten, Grafen (...) geschlagen und (...) geführet worden zu befinden: nach der Ordnung der Bibl. Bücher eingerichtet, Jena, 1703., 13.
35

MSO, Inv. br. Stari fundus. Usp. LISELOTTE POPELKA (bilj. 7), br. 206; HERMINE GÖRICKE-LUKIĆ (bilj. 2), br. 253.

36

Usp. LISELOTTE POPELKA (bilj. 7), br. 204.

37

Tako je, primjerice, Leopold I. na jednoj popularnoj brošuri iz 1689. nazvan Mars orientalis et occidentalis. Usp. JUTTA SCHUMANN, Die andere Sonne. Kaiserbild und Medienstrategien im Zeitalter Leopolds I., Berlin, 2003., 187, 466, sl. 18.

38

Beč, Kunsthistorisches Museum, Inv. Nr. 6509bß, LISELOTTE POPELKA (bilj. 7), br. 231.

39

AMZ, inv. 32304. IVAN MIRNIK (bilj. 2), br. 199; LISELOTTE POPELKA (bilj. 7), br. 232.

40

Usp. LISELOTTE POPELKA (bilj. 7), br. 247, 249.

41

AMZ, inv. 7496. Usp. IVAN MIRNIK (bilj. 2), br. 223; LISELOTTE POPELKA (bilj. 7), br. 246.

42

Usp. KARL GUTKAS (bilj. 27), 25.

43

AMZ, inv. 32396. LISELOTTE POPELKA (bilj. 7), br. 250.

44

U vizualnim medijima toga doba ima bezbroj primjera. Jedan od najpoznatijih je Alegorija cara Leopolda I. kao Herkula, koju je oko 1675. naslikao Gerard Hoet. Usp. Prinz Eugen und das barocke Österreich (bilj. 28), br. 12.1 (autor kat. jedinice Karl Schütz). Također: FRIEDRICH POLLEROSS, "Pro decore Maiestatis", Zur Repräsentation Kaiser Leopolds I. in Architektur, bildender und angewandter Kunst, Jahrbuch des Kunsthistorischen Museums Wien, 40/5 (2002./2003.), 201 i d. Na medaljama iz doba Eugena Savojskoga primjerice: G. W. Vestner i Ph. H. Müller, medalja uz osvajanje Beograda 1717., sprijeda je prikazan Karlo VI., a straga Herkul s odlomljenim rogom Ahelojevim - simbolom pobjede nad polumjesecom. Usp LISELOTTE POPELKA (bilj. 7), br. 236 Na drugoj medalji uz beogradsku pobjedu autora Daniela Warova, koju posjeduje i AMZ, inv. 7465, sprijeda je prikazan Karlo VI., a straga Herkul u borbi s Antejom, v. LISELOTTE POPELKA (bilj. 7), br. 237.

45

LISELOTTE POPELKA (bilj. 7), br. 161. Autor medalje je Philipp Heinrich Müller.

46

Usp., primjerice, veliki list s tezama obranjenim na bečkom sveučilištu posvećen caru Leopodu I. iz 1667. godine, u: SIBYLLE APPUHN-RADTKE, Das Thesenblatt im Hochbarock. Studien zu einer graphischen Gattung am Beispiel der Werke Bartholomäus Kilians, Weißenhorn, 1988., 96 i d.

47

Usp. GEORG LECHNER, Prinz Eugen von Savoyen, Herkules und Apollo seiner Zeit, u: Agnes Husslein-Arco (ur.), Das Winterpalais des Prinzen Eugen, Wien, 2013., 91-99. 


\section{8}

SALOMON KLEINER, Residences Memorables De l'incomparable Heros de nôtre Siecle ou Representation exacte des Edifices et Jardins de Son Altesse Serenissime Monseigneur Le Prince Eugene Francois Duc de Savoye et de Piemont... = Wunder würdiges Kriegs- und Siegs-Lager deß unvergleichlichen Heldens unserer Zeiten. oder Eigentliche Vor und Abbildungen der Hoff-Lust- und Garten Gebäude deß Durchlauchtigsten Fürstens und Herrn Eugenii Francisci Hertzogen zu Savoyen und Piemont... skraćeno: Belvedere-Stichwerk, Augsburg, Jeremias Wolffs Erben, 1731.-1734. Usp. Prinz Eugen und das barocke Österreich (bilj. 28), kat. br. 12. 27 i 12.28. Autor bakroreza je Jakob Sedelmayr Ml.

\section{9}

LISELOTTE POPELKA (bilj. 7), br. 27. Primjerak u Kunsthistorisches Museumu u Beču, Münzkabinett, Inv.-Nr. 1138 bb. Sličan je motiv ponovljen i na medalji $\mathrm{Ph}$. H. Müllera i F. Kleinerta iz 1693. godine, na kojoj je grof Ljudevit Badenski izjednačen s Jošuom, a natpis ga naziva Victor Turcarum perpetuus (Stalni pobjednik nad Turcima). Medalju posjeduje AMZ, inv. 7204. Vidjeti FRIEDRICH POLLEROSS, Das sakrale Identifikationsporträt. Ein höfischer Bildtypus vom 13. bis zum 20. Jahrhundert, 2 sv., Worms, 1988., sv. 1, 92, i sv. II, br. 566, sl. 12; JUTTA SCHUMANN (bilj. 37), 328, 566, sl. 33; HENDRICK ZIEGLER, STAT SOL. LUNA FUGIT. Hans Jacob Wolrabs Josua-Medaille auf Kaiser Leopold I. und ihre Rezeption in Frankreich, u: Christoph Kampmann - Katharina Krause - Eva-Bettina Krems - Anuschka Tischer (ur.), Bourbon - Habsburg - Oranien. Konkurrierende Modelle im dynastischen Europa um 1700., Köln - Weimar - Wien, 2008., 166-181. Prema Ziegleru Sunce na ovoj medalji ima dvostruko značenje: može simbolizirati i Ljudevita XIV. i Leopolda I. (169).

50

Usp. LISELOTTE POPELKA (bilj. 7), 213. Suvremeno tumačenje u: Erklärungen viller zu diesem XVIII. Seculo zu Augspurg und Nürnberg geprägeten Gedächtnuß-Münzen) wie solche von den Herrn Erfindern selbsten in einzelnen Zettlen heraugegeben worden, Lilienfeld, 1731., 99.

51

AMZ, inv. 7468. IVAN MIRNIK (bilj. 2), br. 194; LISELOTTE POPELKA (bilj. 7), br. 234; HERMINE GÖRICKE-LUKIĆ (bilj. 2), br. 258 (primjerak u MSO, kositar).

52

O tome, u vezi s »teologizacijom« i »sakralizacijom« habsburških medalja iz istoga razdoblja, usp. WERNER TELESKO (bilj. 1), 149-153.

\section{3}

MSO, Inv. br. 4838. LISELOTTE POPELKA (bilj. 7), br. 233; HERMINE GÖRICKE-LUKIĆ (bilj. 2), br. 265. H. Göricke-Lukić kao autora navodi J. Vinazera. Prema njoj radi se o osvajanju Beograda 1789. pod generalom Laudonom. Sličan motiv pojavljuje se doista na medalji generala Laudona 1789 . godine, no on je preuzet s Eugenove medalje. Na medalji iz 1717. Eugen je u natpisu označen kao Gideon, a ime generala Laudona bilo je Ernst Gideon, pa je to vjerojatno razlog zabune.

\section{4}

Anagramska igra riječi povezana s imenom vladara i drugih uglednika vrlo je česta u baroknoj komunikaciji. Karakterističan je primjer latinski oblik imena cara Leopolda I., Leopoldus, pretvoren u Pello duos (tjeram dvojicu) kao aluzija na pobjede carske vojske nad Francuzima i Osmanlijama 1689. godine. Usp.
JUTTA SCHUMANN (bilj. 37), 188. Ime Beograda bilo je osobito pogodno za igru riječi. Primjerice, na Mandacherovu medaljonu koji simbolički ilustrira osvajanje Beograda 1717. prikazan je znameniti minobacač koji je pogodio skladište baruta, iznad kojega se nazire sićušan lik Fortune. Gore je natpis: Toto intravit fortuna gradu, Stat. (Punim korakom ušla je fortuna, prema: Stacije, Šume, 3. 3. 85). Pri dnu medalje je natpis: Primus ad Belgradum gradus in turrim pulverariam (Prvi korak prema Beogradu preko spremišta baruta) - EUGEN VICTOR MANDACHER (bilj. 8), 124.

55

Sintagmu »figures hieroglyphiqes« rabi jedan od najuglednijih autora numizmatičke literature toga vremena, NICOLAS CHEVALIER (bilj. 23), 25.

56

Kao moćnoga i snažnog Genija (Pollenti Potentique Genio...), tj. duha zaštitnika, oslovljava ga bakrorez na početku Belvedere - Stichwerka, v. Prinz Eugen und das barocke Österreich (bilj. 28), br. 12. 28. Na jednoj medalji u Mandacherovoj knjizi, Eugen kao dobar anđeo donosi radosnu vijest o pobjedi na Mohačkom polju 1687. godine u liku Merkura koji lebdi između brda Haršanija, u podnožju kojeg se odigrala bitka s dvostrukim ugarskim križem i vedute Beča. Natpis glasi: Reddo Caesari que sunt Caesaris // Nomine et officio bonus angelus 1687. (Vraćam caru carevo // imenom i službom dobri anđeo). EUGEN VICTOR MANDACHER (bilj. 8), 23. Na Mandacherovoj medalji, posvećenoj bitci kod Petrovaradina, prikazan je anđeo s plamenim mačem i natpisom: Misi dominus angelum suum... (Gospodin posla svojega anđela). EUGEN VICTOR MANDACHER (bilj. 8), 114.

57

AMZ, inv. 7621. LISELOTTE POPELKA (bilj. 7), br. 107; ANNA SERENA FAVA, Le medaglie del principe Eugenio di SavoiaSoissons nel medagliere delle raccolte numismatiche Torinesi, Antichità viva, rassegna d'arte, 2 (1968.), br. 7.

58

Eugenius nummis illustratus (bilj. 7), uz str. 231.

59

Njemački prijevod u Eugenius nummis illustratus (bilj. 7) glasi: »Er bricht sich die Bahn, die Hauffen weichen, und die flüchtigen Völker fallen.« U hrvatskom prijevodu Bratoljuba Klaića taj stih glasi: »... tako pred Turnovom silom kad stade da siječe i tuče, sve su se trojanske čete u strahu na bježanje dale.«, Vergilije, Eneida, Zagreb, 1970.

60

AMZ, inv. 7620. LISELOTTE POPELKA (bilj. 7), br. 93. Medalja je opisana i reproducirana u Eugenius nummis illustratus (bilj. 7), str. 194

61 Usp. KARL GUTKAS (bilj. 28), 13.

62

Castrum doloris potanko je opisan u Eugenius nummis illustratus (bilj. 7), 571-582.

63

Poznate su tri Eugenove posmrtne medalje, v. LISELOTTE POPELKA (bilj. 7), br. 257-259. Dvije se čuvaju u AMZ.

64 Primjerak u Beču, Kunsthistorisches Museum, Inv. Nr. 6516bß. LISELOTTE POPELKA (bilj. 7), br. 257. 
65

AMZ, inv. 7623. IVAN MIRNIK (bilj. 2), br. 226; LISELOTTE POPELKA (bilj. 7), br. 258; Od svagdana do blagdana (bilj. 2), 375 (autor Ivan Mirnik); Eugenius nummis illustratus (bilj. 7), 579.

66

AMZ, inv. 7624. IVAN MIRNIK (bilj. 2), br. 227; LISELOTTE POPELKA (bilj. 7), br. 259.

67

Medaljeru je kao predložak vjerojatno poslužio portret princa u starijoj dobi sličan onima koje je izrađivao Jan Kupetzky. Sličan je reproduciran u: Prinz Eugen und das barocke Österreich (bilj. 28), br. 18, 48. Prema autoru opisa Karlu Gutkasu: »Slika je potpuno samostalan rad neusporediv s bilo kojim drugim portretnim tipom. « Gutkas je datira oko 1720. godine. Među- tim, taj portret vrlo je sličan onome što ga je oko 1727. izradio Johann Gottfried Auerbach (Berlin, Schloss Charlottenburg). Usp. Prinz Eugen und das barocke Österreich, FB 17. i KARL GUTKAS (bilj. 28), 26 i d.

68

Usp. JOHANNES FEICHTINGER - JOHANN HEISS (bilj. 1), 15.

69

Usp. ROLAND BARTHES, Retorika slike, u: Nenad Miščević - Milan Zinaić (prir.), Plastički znak. Zbornik tekstova iz teorije vizualnih umjetnosti, Rijeka, 1982., 71.

70

Tako ga na kraju svoje knjige naziva EUGEN VICTOR MANDACHER (bilj. 8), 139.

Milan Pelc

\section{Utilissimus reipublicae princeps - Eugene of Savoy and the Rhetoric of Baroque Medals}

Judging by the number of issued medals, Eugene of Savoy was one of the most popular men of his time. His popularity was, like himself, in the service of promoting the ruler and the Empire, for which he fought successfully on many battlefields from northern Italy to the Balkans. Medals dedicated to Eugene of Savoy provide a representative insight into Baroque visual symbolism as a component of the public promotion of a prominent individual. Due to his military successes as an army leader of three Habsburg emperors - Leopold I, Joseph I, and Charles VI - Prince Eugene of Savoy entered the broadly based iconographic program of monarchical promotion. Since a good part of Eugene's military activity was directly related to the liberation of Croatian historical lands from the Ottomans, it is not surprising that the two largest numismatic collections in northern Croatia, those of the Archaeological Museum in Zagreb and the Museum of Slavonia in Osijek, include a significant number of medals dedicated to the celebrated military leader. Although this paper focuses primarily on the presentation and interpretation of these visual sources, other medals and depictions from relevant contemporary publications dedicated to the famous military leader have been used as well for a fuller understanding of the visual rhetoric that helped create the image of Eugene of Savoy. These primarily include two biographies of Prince Eugene illustrated with medals: E. Victor Mandacher, Acta serenissimi principis Eugenii Francisci Sabaudiae et Pedemontij Ducis (...), Vienna, 1735, and Eugenius nummis illustratus, Nuremberg, 1736.

As easily transferable, durable, materially and aesthetically valuable objects of representation and memory, medals had been a "currency of fame" ever since the Renaissance. This social aspect is also evident in the medals of Prince Eugene of Savoy. No imperial military leader in the period after the siege of Vienna, although some of them, such as Charles of Lorraine or Louis of Baden, played prominent roles in the war operations aimed at liberating the Kingdom of Hungary, gained as much popularity as Prince Eugene if judged by the production of medals. Iconographic analysis of his medals reveals the mytho-poetics of the imperial military leader, achieved with the help of rhetorical tools of the Baroque visual propaganda, primarily through the abundant use of expressive motifs of portraiture, mythological, biblical, emblematic, and historical-topographical provenance. In these medals, Prince Eugene was presented to the public as a prominent member of the military and political elite, above all loyal and useful to his rulers and the state (utilissimus reipublicae princeps). His victories in great battles were used to foster the political propaganda of the Habsburg Monarchy, with the army leader appearing as an extended military arm of the three emperors - Leopold I, Joseph I, and Charles VI or as their alter ego in promoting the interests of the Empire.

No military leader had as much success in the wars for the Habsburg imperial house as Prince Eugene of Savoy. Fighting and triumphing on two fronts, Eugene was stylized as victor not only over the Ottomans, but also over the French, who were the main Christian enemies of the Austrian crown. In the communicational perspective of his time, he therefore appeared both as a liberator and protector of Christians and as an avenger over the injustices inflicted on the Empire: Patiens vocari caesaris ultor (He may be called the emperor's avenger). As the commander-in-chief and the chairman of the court war council (Hofkriegsraat), Prince Eugene actively 
carried out the military plans of the Habsburg emperors: his successes were their successes and his representation was also theirs. He therefore shared a place on medals with the emperors, be it in effigy or in inscriptions, or in an allegorical scene. The medallists who created his public image primarily borrowed from the repertoire of imperial propaganda the symbolic identification with the heroes of ancient mythology, Mars, Minerva and Hercules, who appear on medals (and generally in the visual arts) as the most common mythological equivalents of the royal and military virtues of Emperors Leopold I, Joseph I, and Charles VI. Identification with biblical figures, especially the Old Testament heroes of Israel such as Gideon and Joshua, was also among the favourite rhetorical figures intended to glorify victors in battles against superior enemies, especially if they were also enemies of Christendom. Thus, on the medals of Eugene of Savoy, instrumentalization of biblical typology serves to offer a "theological" interpretation of historical events that took place in accordance with the decisions of God's providence and as a result of God's intervention. The analysed medals clearly demonstrate the tendency of the medallists to unite two key features in the numismatic image of Eugene of Savoy: one emphasized the military and heroic character of his merits, and the other his uncompromising loyalty to the monarchy and the ruler. In line with this endeavour, the commonplaces of Baroque rhetorical repertoire were individualized and adapted to Eugene's enormous role in the political arena of the time.

Keywords: Eugene of Savoy, Baroque medals, Leopold I, Joseph I, Charles VI 